\title{
Nitrogen and phosphorus limitations induce carbon partitioning and membrane lipid remodelling in the marine diatom Phaeodactylum tricornutum
}

\author{
Huang Bing ${ }^{1}$, Marchand Justine ${ }^{1}$, Blanckaert Vincent ${ }^{2}$, Lukomska Ewa ${ }^{3}$, Ulmann Lionel 2, \\ Wielgosz-Collin Gaëtane ${ }^{4}$, Rabesaotra Vony ${ }^{4}$, Moreau Brigitte ${ }^{1}$, Bougaran Gael ${ }^{3}$, Mimouni Virginie 2 , \\ Morant-Manceau Annick ${ }^{1,}{ }^{*}$
}

${ }^{1}$ Laboratoire Mer, Molécules, Santé (IUML - FR 3473 CNRS), UFR Sciences et Techniques, Le Mans Université, avenue Olivier Messiaen, 72085 Le Mans cedex 09, France

2 Laboratoire Mer, Molécules, Santé (IUML - FR 3473 CNRS), IUT Génie Biologique, Le Mans Université, 52 rue des Docteurs Calmette et Guérin, 53020 Laval cedex 9, France

${ }^{3}$ Laboratoire Physiologie et Biotechnologie des Algues, IFREMER, rue de l'lle d'Yeu, BP 21105, 44311

Nantes Cedex 03, France

${ }^{4}$ Laboratoire Mer, Molécules, Santé (IUML - FR 3473 CNRS), UFR Sciences pharmaceutiques et biologiques, Université de Nantes, 9 rue Bias, 44035 Nantes, France

* Corresponding author : Annick Morant-Manceau, email address : annick.manceau@univ-lemans.fr

\begin{abstract}
:
Nitrogen (N) and phosphorus (P) limitations induce triacylglycerol (TAG) accumulation and membrane lipid remodelling in the marine diatom Phaeodactylum tricornutum. However, a clear understanding of the metabolic reorientation is still lacking. Carbon partitioning is of great interest because this microalga produces various highly valuable molecules such as lipids and polyunsaturated fatty acids. This study compared growth, photosynthetic activity, biochemical and transcriptional responses of $\mathrm{P}$. tricornutum throughout batch culture under $\mathrm{N}$ or $\mathrm{P}$ limitation. The integrated results show that the photosynthetic intensity was greatly reduced under $\mathrm{N}$ or $\mathrm{P}$ limitation. Under $\mathrm{N}$ limitation, the degradation and re-use of cellular N-containing compounds contributed to TAG accumulation, whilst P limitation favoured TAG accumulation due to the efficiency of carbon fixation, without massive degradation of essential compounds at cellular level. There was no difference in the partitioning of carbon to neutral lipids between $\mathrm{N}$ and $\mathrm{P}$ limitation. Substitution of phospholipids with betaine lipids appeared to be a P-specific acclimation strategy in P. tricornutum, which was largely regulated at the gene expression level. Betaine lipid synthesis was induced by $\mathrm{P}$ limitation. The lipid remodelling began once the medium became deficient in $\mathrm{P}$. While the phospholipid biosynthesis pathway was not completely inhibited, a shift of lipid classes occurred immediately after their synthesis via phospholipid-recycling mechanisms.
\end{abstract}

Keywords : Betaine lipid, lipid remodelling, microalga, nitrogen, phosphorus, polyunsaturated fatty acid 


\section{Introduction}

Microalgae belonging to the diatom taxon are major players in the ocean carbon cycle because they fix about 10 billion tonnes of inorganic carbon (Ci) per annum, representing around $40 \%$ of total marine primary productivity. Diatoms are characterized by a siliceous cell wall and originated from a secondary endosymbiosis in which a red alga was engulfed by a non-photosynthetic eukaryote (Armbrust et al., 2004; Wilhelm et al., 2006; Bowler et al., 2008; Deschamps \& Moreira, 2012). As a result, the diatom genome resembles a mosaic of genes that regulates a metabolic network unique in the plant kingdom (Bowler et al., 2008; Curtis et al., 2012). Diatoms have also developed sophisticated mechanisms to survive under changing environmental conditions (Scala \& Bowler, 2001).

Nitrogen $(\mathrm{N})$ is often considered the main limiting nutrient in much of the surface of low-latitude oceans, while phosphorus (P) limitation hasbeen observed in the Mediterranean, Gulf of Mexico and Red Sea (Moore et al., 2013; Brembu et al., 2017). When diatoms are in nutrient-replete waters, as along marine coasts, their growth rate is high and they store carbohydrates in vacuoles in the form of chrysolaminarin $(\beta-1,3-$ glucan polymer). However, when facing nutrient deprivation, as in the open ocean far from land, diatoms mainly produce neutral lipids (triacylglycerol, TAG) in oil bodies (Maeda et al., 2017), which can account up to 40-60\% of their biomass (Chisti, 2007; Satoh et al., 2013; Zienkiewicz et al., 2016). This reorientation of carbon metabolism has attracted attention as a potential means of producing neutral lipids and biofuel without using oleaginous plants.

$\mathrm{N}$ and $\mathrm{P}$ limitations have both been studied with regard to their influence on the reorientation of carbon flux and cellular energy (Falkowski \& Raven, 2007; Valenzuela et al., 2012; Yang et al., 2014; Alipanah et al., 2015, 2018; Levitan et al., 2015; Lin et 
al., 2016; Brembu et al., 2017). Indeed, they are essential chemical components of many biomolecules, and each has its own specific use: $\mathrm{N}$ is mainly used to synthesize proteins, chlorophylls and nucleic acids, while $\mathrm{P}$ isa constituent of nucleic acids, ATP and phospholipids (Geider \& La Roche, 2002). Thus, these two elements play different roles in cell metabolism. Even though scarcity of either $\mathrm{N}$ or P triggers TAG accumulation, the acclimation strategies of cells might be quite different. Significant research efforts are still needed to compare cellular response to $\mathrm{N}$ or $\mathrm{P}$ availability in order to improve TAG production efficiency.

When faced with P limitation, changes in lipid classes are often observed in microalgae, characterized by an increase of non-phosphorous lipids (Khozin-Goldberg \& Cohen, 2006; Van Mooy et al., 2009; Abida et al., 2015; Shemi et al., 2016; Cañavate et al., 2017a, b). Betaine lipids (BL) are non-phosphorous lipids in the non-plastid membranes (Kato et al., 1996). Three types of BL have been identified up to now: diacylglycerol trimethylhomoserine (DGTS), diacylglycerol hydroxymethyl-N,N,Nmethyl- $\beta$-alanine (DGTA), and diacylglycerol-3-carboxymethyl-choline (DGCC). DGTA and DGTS were detected in the diatom Phaeodactylum tricornutum (Abida et al., 2015; Popko et al., 2016; Cañavate et al., 2017a, b), where DGTA is the dominant BL. Moreover, under P deprivation, phosphatidylcholine (PC) was replaced with DGTA (Abida et al., 2015; Cañavate et al., 2017b). This membrane remodeling induced by $\mathrm{P}$ starvation has already been corroborated by a measured up-regulation of genes encoding phospholipases and a putative DGTA synthesis enzyme (Cruz de Carvalho et al., 2016). However, a clear view of the different steps leading to such membrane remodeling in $P$. tricornutum is still lacking. 
The aim of our work was to study different cellular acclimation strategies of $P$. tricornutum subjected to $\mathrm{N}$ or $\mathrm{P}$ limitation. For this purpose, the impact of $\mathrm{N}$ and $\mathrm{P}$ limitations on the metabolic reorientation in P. tricornutum was compared, particularly with respect to polar lipid biosynthesis and composition. Photosynthetic activity of the diatom, residual $\mathrm{N}$ and $\mathrm{P}$ concentrations in the media, and different biochemical and transcriptional responses of $P$. tricornutum were measured throughout the experimental culture period.

\section{Materials and methods}

\section{Growth conditions}

All cultures of the diatom $P$. tricornutum Bohlin (UTEX 646, Pt4) were axenic. Theywerecarried out in a medium aerated by sterile-filtered air under continuous fluorescent light (Osram 54W cool daylight) with a photon flux density of $300 \mu \mathrm{mol}$ photons $\mathrm{m}^{-2} \mathrm{~s}^{-1}$, at $22 \pm 2^{\circ} \mathrm{C}$. The diatoms were grown in a control medium composed of natural seawater (Saint Malo, France) enriched with Walne solution (Walne, 1966) until the exponential growth phase. Cells were then harvested by centrifugation $(1000 \times g, 15$ min) and transferred into non-enriched seawater, acclimated for 2 days, in order to lower the cellular $\mathrm{P}$ and $\mathrm{N}$ quotas and to minimize $\mathrm{N}$ and $\mathrm{P}$ input to the subsequent cultures. Cells were then inoculated at an initial density of $10^{5}$ cells $\mathrm{ml}^{-1}$ into 1.51 of medium prepared with seawater enriched with classic non-modified Walne solution (NP, control) or modified Walne (P-limited or N-limited) solutions. The non-modified or modified Walne solutions provided nutrient concentrations of $1176 \mu \mathrm{M} \mathrm{NO}_{3}{ }^{-}$and $128 \mu \mathrm{M} \mathrm{PO}_{4}{ }^{3-}$ $(\mathrm{N}: \mathrm{P}=9.18)$ in the control medium, $500 \mu \mathrm{M} \mathrm{NO}_{3}{ }^{-}$and $4 \mu \mathrm{M} \mathrm{PO}_{4}{ }^{3-}(\mathrm{N}: \mathrm{P}=125)$ in the $\mathrm{P}-$ limited medium and $125 \mu \mathrm{M} \mathrm{NO}_{3}{ }^{-}$and $125 \mu \mathrm{MPO}_{4}{ }^{3-},(\mathrm{N}: \mathrm{P}=1)$ in the $\mathrm{N}$-limited medium. 
At least three biological replicates of batch cultures were studied for each of the mentioned conditions. Cell density was assessed using a Neubauer hemocytometer. Specific growth rate $(\mu)$ was calculated according to the equation: $\mu=\left(\ln N_{t 2}-\ln N_{t 1}\right) /$ (t2-t1), where $\mathrm{N}_{\mathrm{t} 2}$ and $\mathrm{N}_{\mathrm{t} 1}$ are the numbers of cells on two consecutive culture days ( $\mathrm{t} 2$ and t1). Cell volume was estimated using the geometric "half parallelepiped" model according to the equation: $\mathrm{V}=\left(\mathrm{a} \times \mathrm{b}^{2}\right) / 2$, where $\mathrm{a}$ and $\mathrm{b}$ represent the length and the width of cells, respectively (Olenina et al., 2006). These two dimensions were determined using a light microscope and the ZEN imaging software (Carl Zeiss Microscopy, Jena, Germany).

\section{Nutrient analyses}

Defined volumes of the cultures containing about $30 \times 10^{6}$ cells were filtered on GF/C glass fiber filters (Whatman, Fisher Scientific, Illkirch, France). Inorganic nutrients were measured in the filtrates. $\mathrm{NO}_{3}{ }^{-}$was determined by ultraviolet spectrophotometry (American Public Health Association, 1992), and $\mathrm{PO}_{4}{ }^{3-}$ was estimated by visible spectrophotometry (Murphy \& Riley, 1958). Cells on the filters were then washed twice with $10 \mathrm{ml} 0.516 \mathrm{M} \mathrm{NaCl}$, dried overnight at $60^{\circ} \mathrm{C}$ and stored at $-20^{\circ} \mathrm{C}$. Particulate carbon and nitrogen in cells were determined by elemental analysis (FLASH 2000 NC analyzer, Thermo Fisher Scientific, Villebon sur Yvette, France).

\section{Photosynthesis and chlorophyll fluorescence yield measurements}

Photosynthetic intensity was measured by the rate of oxygen evolution as previously described (Nguyen-Deroche et al., 2012), using a thermostated chamber for temperature control $\left(22^{\circ} \mathrm{C}\right)$ equipped with a luminescent oxygen indicator (Pyroscience FireSting $\mathrm{O}_{2}$, 
Aachen, Germany). Net photosynthesis was measured under actinic irradiance of 300 $\mu$ mol photons $\mathrm{m}^{-2} \mathrm{~s}^{-1}$ (Intralux 4000-1, Schlieren, Switzerland) and respiration was measured in the dark. Chlorophyll $a$ (Chl) fluorescence yield measurements were performed using a FMS1-modulated fluorimeter (Hansatech, Cergy, France) (Roháček et al., 2014). After a dark-adaptation period (15 min), the minimum Chl fluorescence yield $\left(\mathrm{F}_{0}\right)$ was recorded under weak modulated light (less than $15 \mu \mathrm{mol}$ photons $\left.\mathrm{m}^{-2} \mathrm{~s}^{-1}\right)$. Next, a saturation pulse (more than $1200 \mu \mathrm{mol}$ photons $\mathrm{m}^{-2} \mathrm{~s}^{-1}$ ) was applied to determine the maximum fluorescence yield $\left(\mathrm{F}_{\mathrm{m}}\right)$. Non-photochemical quenching (NPQ) was determined after $7 \mathrm{~min}$ of non-saturating white actinic irradiation with a photon flux density corresponding to the growth photon flux density and a saturation pulse that allow measuring the maximum fluorescence yield in the light $\left(F_{m}\right.$ '). NPQ was calculated according to the equation: $\mathrm{NPQ}=\left(\mathrm{F}_{\mathrm{m}}-\mathrm{F}_{\mathrm{m}}{ }^{\prime}\right) / \mathrm{F}_{\mathrm{m}}$ '. For quenching component analysis, a higher actinic irradiance $\left(1000 \mu \mathrm{mol}\right.$ photons $\left.\mathrm{m}^{-2} \mathrm{~s}^{-1}\right)$ was applied, and dark relaxation of the $\mathrm{Chl}$ fluorescence yield was recorded.

\section{Protein, carbohydrate, neutral lipid and pigment levels}

Cells were harvested by centrifugation $(3000 \times g, 10 \mathrm{~min})$. For protein and carbohydrate assays, about $30 \times 10^{6}$ cells were washed with $0.516 \mathrm{M} \mathrm{NaCl}$, resuspended in ultrapure water, and then disrupted by homogenization $(6.0 \mathrm{~m} / \mathrm{s}, 10 \mathrm{~s}$, Lysing Matrix D, FastPrep24 5G, Strasbourg, France). The homogenate was centrifuged at $4^{\circ} \mathrm{C}, 16100 \times g$ for 20 min, and the lysate was used for both protein and carbohydrate quantifications. Soluble protein content was quantified using the Bradford method (Bradford, 1976), and soluble carbohydrate content was determined by the phenol-sulfuric acid method (Dubois et al., 1951). 
Cellular neutral lipid accumulation was estimated by Nile Red (Sigma-Aldrich, Saint-Quentin Fallavier, France) fluorescence (Chen et al., 2009). In brief, about $3 \times 10^{6}$ cells were resuspended in $3 \mathrm{ml} 25 \%$ DMSO (v/v), and then stained with $1.5 \mu 1$ Nile Red solution (1 $\mathrm{mg} \mathrm{ml}^{-1}$ in acetone). Fluorescence was measured at excitation/emission wavelengths of 530/580 nm, respectively (Perkin Elmer LS-55, Villebon sur Yvette, France).

Pigments were extracted from the cell pellet with $100 \%$ acetone and quantified spectrophotometrically (Perkin Elmer Lambda-25, Villebon sur Yvette, France) as described in Heydarizadeh et al., (2017).

\section{Lipid extraction and identification, and fatty acid analysis}

About $300 \times 10^{6}$ cells were collected on days 2, 4 and 7 on a GF/C glass fiber filter (Whatman, Fisher Scientific, Illkirch, France). Total lipids were extracted in a chloroform/ methanol/ 0.28\% NaCl (1/2/0.2, v/v/v) mixture (Bligh \& Dyer, 1959). The solvent was then evaporated under partial vacuum using a rotary evaporator (Heidolph 94200, Fisher Scientific, Illkirch, France). Dry extracts were stored in $2 \mathrm{ml}$ pure chloroform at $-20^{\circ} \mathrm{C}$ under nitrogen. Total lipid content was quantified by spectrophotometry after carbonization (Marsh \& Weinstein, 1966) using triacylglycerol as a standard (Sigma Aldrich, Saint-Quentin Fallavier, France).

Lipid classes were separated using high performance thin layer chromatography (HPTLC) on $20 \times 20 \mathrm{~cm}$ silica gel 60 plates (Merck, Fontenay sous Bois, France). The silica plates were washed with isopropanol to eliminate impurities, and then activated for $30 \mathrm{~min}$ at $120^{\circ} \mathrm{C}$ before use. Lipid extracts from about $7.5 \times 10^{6}$ cells were deposited using a semi-automatic TLC Sampler (Camag Linomat V, Muttenz, Switzerland), and 
separated in TLC chambers. Three separation solvents were successively used: (1) methyl acetate/ isopropanol/ chloroform/ methanol/ $0.25 \% \mathrm{KCl}(25 / 25 / 25 / 10 / 9$, v/v/v/v/v), (2) methyl acetate/ isopropanol/ chloroform/ methanol/ $0.25 \% \mathrm{KCl}(5 / 5 / 5 / 2 / 1, \mathrm{v} / \mathrm{v} / \mathrm{v} / \mathrm{v} / \mathrm{v})$ and (3) hexane/ diethyl ether/glacial acetic acid (40/10/1, v/v/v). Lipids were visualized under UV light (366 nm) after spraying with primuline (Sigma-Aldrich, Saint-Quentin Fallavier, France) (White et al., 1998). Quantification was achieved with a digital image system (Versadoc 3000 Bio-Rad, Marnes la Coquette, France) in combination with the program Quantity One (Bio-Rad, Hercules, USA). Visualization of phosphorous lipids was carried out by spraying with Zinzadze reagent (Molybdenum Blue Spray, Sigma-Aldrich, SaintQuentin Fallavier, France) (Dittmer \& Lester, 1964). All lipid standards used for HPTLC analyses were obtained from Sigma-Aldrich (Saint-Quentin Fallavier, France) or Advanti Polar Lipids (Alabaster, USA).

Lipid spots were further identified by the method of Huang et al. (1999), using a mass spectrometer (LCQ, Thermo Finnigan, San Jose, CA, USA) equipped with an electrospray ionization source (ESI) and an ion trap analyzer (IT). Lipids recovered from the silica powder were dissolved in pure methanol $\left(10 \mu \mathrm{g} \mathrm{ml}^{-1}\right)$ and then injected directly into the ESI probe at a flow rate of $3 \mu 1 \mathrm{~min}^{-1}$. Mass analyses were conducted in both positive and negative modes. All data were acquired and analyzed by LCQ Xcalibur software (Thermo Finnigan, San Jose, CA, USA).

Lipid fractions were separated using a column of 500 mg silica gel 60 (normalphase, 0.063-0.200 mm, Merck, Fontenay-sous-Bois, France), preconditioned with pure chloroform. Pre-concentrated crude lipid samples were loaded on the columns. Neutral lipids were eluted with $20 \mathrm{ml}$ chloroform/ acetone (9/1, v/v), glycolipids with $4 \mathrm{ml}$ chloroform/ methanol (5/2, v/v) and $6 \mathrm{ml}$ acetone/ methanol (9/2, v/v), and phospholipids 
and betaine-lipids with $20 \mathrm{ml}$ methanol/ $\mathrm{H}_{2} \mathrm{O}(9 / 1$, v/v). The fractions eluted were evaporated and dissolved in $2 \mathrm{ml}$ pure chloroform for subsequent analysis.

Fatty acid methyl esters (FAMEs) were obtained as previously described (Slover \& Lanza, 1979). FAMEs were analyzed with a Focus gas-chromatograph (Thermo Electron Corporation, Les Ulis, France) equipped with a capillary column CP Sil-88 25 $\mathrm{m} \times 0.25 \mathrm{~mm}$ (Varian, Les Ulis, France). Nitrogen was used as the mobile phase with a constant flow rate of $1 \mathrm{ml} / \mathrm{min}$. Injection was performed in split mode at $250^{\circ} \mathrm{C}$. Analyses were carried out from $120^{\circ} \mathrm{C}$ to $220^{\circ} \mathrm{C}: 120^{\circ} \mathrm{C}$ for $4 \mathrm{~min}, 120-220^{\circ} \mathrm{C}$ with $6^{\circ} \mathrm{C} / \mathrm{min}$, and held at $220^{\circ} \mathrm{C}$ for $5 \mathrm{~min}$. FAMEs were detected with a flame-ionization detector, analyzed with the software Azur V4 (Datlys, Les Ulis, France), identified from authentic FAME standards (Sigma-Aldrich, Saint-Quentin Fallavier, France), and expressed as molar percent of total fatty acids.

\section{mRNA quantification}

At days 2, 4 and 7, corresponding to the exponential growth phase and early and late stationary growth phases, respectively, about $100 \times 10^{6}$ cells were harvested by vacuum filtration on a precombusted $\left(150^{\circ} \mathrm{C}, 6 \mathrm{~h}\right) 47 \mathrm{~mm}$ GF/C glass fiber filter (Whatman, Fisher Scientific, Illkirch, France), then immediately frozen in liquid nitrogen and stored at $80^{\circ} \mathrm{C}$. Total RNA was extracted using the Spectrum Total RNA kit (Sigma-Aldrich, SaintQuentin Fallavier, France) including on-column DNase digestion by DNase I (SigmaAldrich, Saint-Quentin Fallavier, France) following the manufacturer's protocol. The quality and concentration of the eluted RNA were determined by UV absorbance at 260 and $280 \mathrm{~nm}$ (Nanodrop 2000c, Thermo Fisher Scientific, Villebon sur Yvette, France). A total of $1 \mu \mathrm{g}$ of RNA was reverse transcribed, following the M-MLV Reverse 
Transcriptase (Promega, Charbonnières les Bains, France) protocol. cDNA samples were diluted 10 times before quantitative real-time PCR (qRT-PCR) analysis.

Reactions were performed on a StepOnePlus Real-Time PCR system (Applied Biosystems, Villebon sur Yvette, France), with the standard cycling program composed of a pre-incubation for $2 \mathrm{~min}$ at $95^{\circ} \mathrm{C}$, followed by 40 cycles of amplification: $95^{\circ} \mathrm{C}$ for $15 \mathrm{~s}, 60^{\circ} \mathrm{C}$ for $1 \mathrm{~min}$, and a final melting analysis $\left(60-95^{\circ} \mathrm{C},+0.3^{\circ} \mathrm{C} / 30 \mathrm{~s}\right)$. The threshold cycle $\left(C_{t}\right)$ value for individual reactions was determined by analysis of raw fluorescence data using the PCR Miner program (Zhao \& Fernald, 2005).

Ten housekeeping gene (HKG) candidates: TBP (TATA box binding protein), RPS (ribosomal protein small subunit 30S), Ub (ubiquitin), H4 (Histone 4), Actin12, Actin16, TubA (tubulin $\alpha$ ), TubB (tubulin $\beta$ ), EF1a (elongation factor $1 \alpha$ ), and CdKA (Cyclin-dependent kinase A) were studied using the Bestkeeper program (Pfaffl et al., 2004). The most stable genes (displaying weak $C_{t}$ standard deviation and high pair-wise correlation) were selected as the endogenous references to accurately normalize the target gene transcriptions. The transcriptional fold change of a target gene was calculated using the $\Delta \Delta \mathrm{C}_{\mathrm{t}}$ method (Livak \& Schmittgen, 2001), calibrated to the day-2 control cultures (exponential growth phase). Based on the KEGG (Kyoto Encyclopedia of Genes and Genomes) pathway assignments, we selected 28 genes/isogenes coding for 10 enzymes involved in TAG and membrane lipid biosynthetic pathways. The locations of the corresponding enzymes or isoenzymes have not yet been precisely determined. The primer sets used are summarized in Supplementary Table S1. 


\section{Statistical analysis}

Means comparisons were tested using a one-way repeated measures ANOVA followed by a Fisher's LSD post-hoc test. In all cases, a $\mathrm{p}$ value $\leq 0.05$ was considered to be statistically significant. Where not specified otherwise, the SIGMAPLOT software package was used for all statistical calculations. All results are expressed as means of at least three independent cultures with standard errors.

\section{Results and discussion}

\section{Effect of $\mathbf{N}$ and $P$ limitations on growth}

Cell growth of $P$. tricornutum was monitored over 9 days in batch cultures (Fig. 1A-D). The N-limited (N-) and P-limited (P-) cultures showed similar cell density evolution compared with non limited (NP) cultures until day 3 . The specific growth rate reached its maximum $\left(\mu_{\max }=1.1 \mathrm{~d}^{-1}\right)$ on day 2 under the three cultivation conditions (Fig. 1A). The growth rates were then significantly reduced from day 4 onwards: about 1 day following $\mathrm{N}$ deprivation $\left(\mathrm{NO}_{3}{ }^{-}\right.$concentration lower than the detection limit) (Fig. 1C) and 2 days following $\mathrm{P}$ deprivation $\left(\mathrm{PO}_{4}{ }^{3-}\right.$ concentration lower than the detection limit) in $\mathrm{N}$ - and $\mathrm{P}-$ limited cultures, respectively (Fig. 1D). The longer time required to observe the effects of P-limitation following P-depletion in the medium might reflect rapid uptake and storage of $\mathrm{P}$, followed by utilization of stored $\mathrm{P}$ reserves.

The same reduction of carbon content per cell was observed in the three culture conditions during the exponential growth phase, then carbon was accumulated in Plimited cells whereas $\mathrm{C}$ content stayed constant in the two other conditions (Fig. 2A). The increase in carbon per cell in the P-limited cultures during stationary phase was at least partly due to an increase in cell volume. The average cell volume tended to increase in P- 
limited cells by $15 \%$ and to decrease in N-limited cells by $13 \%$ on day 7 (Supplementary Fig. S1). The cellular N/C ratio remained very low in the N-limited cultures from day 4 onwards (Fig. 2B). In P-limited cells, the N/C ratio was also highly reduced, suggesting that the ability to assimilate nitrogen was restricted by $\mathrm{P}$ limitation, as previously observed in another strain of $P$. tricornutum (Terry et al., 1985). This low $\mathrm{N}$ assimilation could be related to the need for ATP for active N-uptake (Pahlow \& Oschlies, 2009; Bougaran et al., 2010). The large decrease in the cellular N/C ratio in the P limited cells could also be linked to the large need for phosphorus in transcriptional and ribosomal RNA, which is essential for the synthesis of proteins, the main $\mathrm{N}$ pool in the cell (Geider \& La Roche, 2002).

The maximum cell density was $84 \%$ lower in N-limited cultures $\left(\sim 2.7 \times 10^{6}\right.$ cells $\left.\mathrm{ml}^{-1}\right)$ and $88 \%$ lower in P-limited cultures $\left(\sim 2.0 \times 10^{6}\right.$ cells $\left.\mathrm{ml}^{-1}\right)$ compared with control cultures (Fig. 1B-D). In nutrient-limited cultures, days 2, 4 and 7 were chosen, according to the growth rate evolution, to represent the exponential growth phase, early stationary phase $\left(\mu \sim 0.2 \mathrm{~d}^{-1}\right)$ and late stationary phase, respectively, for subsequent experiments. It was noted that control cells reached early stationary phase on day 7 .

\section{Effect of $\mathrm{N}$ and $\mathrm{P}$ limitations on photosynthetic activity}

Fig. 3A-C shows that the cellular $\mathrm{Chl} a, \mathrm{Chl} \mathrm{c}$, and fucoxanthin (the major carotenoid in diatoms), normalized to cell $\mathrm{C}$, were highly increased in the control cultures, which could be due to light-limitation that occurs in dense cultures (Beale \& Appleman, 1971). On the contrary, the pigment/C ratios were greatly decreased in the N-limited cultures. Similar results were also obtained in previous studies (Geider et al., 1993; Alipanah et al., 2015). The large reduction in cellular $\mathrm{Chl} a / \mathrm{C}$ ratios likely reduced the number of PSI and PSII 
complexes. Because these three pigments are involved in light harvesting and excitation energy transfer to the reaction centers (Geider et al., 1993), such a decline could directly induce a dysfunction of the photosynthetic machinery. Thus a reduction of gross photosynthesis was observed during $\mathrm{N}$ limitation (Fig. 4A). A similar reduction in photosynthetic activity has been reported previously in transcript levels of genes involved in photosynthesis under N scarcity (Yang et al., 2013; Alipanah et al., 2015; Levitan et al., 2015). The pigment contents were less affected in P-limited cultures (Fig. 3A-C). These results are in accordance with an increased expression of photosynthetic proteins during $\mathrm{P}$ depletion, as reported in a previous study (Yang et al., 2014). However, a reduction of photosynthetic ratewas observed during P deprivation (Fig. 4A). In P-limited plants, such a decline of photosynthetic rate was related to a depletion of phosphorylated intermediates of the Calvin-Benson cycle (Brooks, 1986; Jacob \& Lawlor, 1993).

The maximum quantum yield $\left(\mathrm{F}_{\mathrm{v}} / \mathrm{F}_{\mathrm{m}}\right)$, which quantifies the maximum photochemical efficiency of PSII (Roháček et al., 2008), decreased significantly in Nlimited $\left(F_{v} / F_{m}=0.60\right)$ and P-limited cultures $\left(F_{v} / F_{m}=0.61\right)$ on day 4 , compared with control cultures $\left(F_{v} / F_{m}=0.66\right)(F i g .4 B)$, suggesting a reduced photosynthetic capacity of the PSII reaction centers under both $\mathrm{N}$ - and P-limitation. A similar decrease in response to $\mathrm{N}$ and $\mathrm{P}$ limitations was recently reported in P. tricornutum by Alipanah et al. (2015, 2018). The efficiency of the electron transport $\left(\Phi_{\text {II }}\right)$ in the light (Fig. 4C) declined in NP cells at day 7 compared with day 2 indicating that PSII photochemistry was affected by nutrient depletion (Fig. 1B) and light limitation. $\Phi_{\text {II }}$ decreased more intensively in Plimited cultures than in $\mathrm{N}$-limited cultures during the stationary phase. This decrease might be due to the deficiency in $\mathrm{NADP}^{+}$, ADP and inorganic $\mathrm{P}$, which slows down the electron transport rate (Chylla \& Whitmarsh, 1989; Wykoff et al., 1998). 
Non-photochemical quenching (NPQ) is an important mechanism of heat dissipation that allows a balance to be maintained between the absorbed photon energy and the energy utilized; it also avoids the formation of reactive oxygen species (ROS). In the present study, NPQ increased in both N- and P-limited cultures on day 4, but much more strongly under P deprivation during stationary phase (Fig. 4D). To get further insight into the underlying mechanisms, we focused on the relaxation period. As reported by (Roháček et al., 2014), three individual components of non-photochemical quenching (qN) of variable Chl fluorescence: $\mathrm{qN}_{\mathrm{f}}$ (s time-scale), $\mathrm{qN}_{\mathrm{i}}$ (min time-scale) and $\mathrm{qN}_{\mathrm{s}}(\mathrm{h}$ time-scale) were studied (Supplementary Fig. S2). $\mathrm{qN}_{\mathrm{f}}$, which is considered to be related to a fast conformation change occurring within the thylakoid membranes at the start of the relaxation process (Roháček et al., 2014), almost disappeared in N- and P-limited cultures compared with control cultures (Fig. 4E), suggesting a modification at the membrane level. The decrease of $\mathrm{qN}_{\mathrm{f}}$ was compensated by the amplification of $\mathrm{qN}_{\mathrm{s}}$ and $\mathrm{qN}_{\mathrm{i}}$ in $\mathrm{N}$ - and $\mathrm{P}$-limited cultures, respectively (Fig. 4E). In $\mathrm{N}$-limited cultures, $\mathrm{qN}_{\mathrm{i}}$ remained unaffected, while the proportion of $\mathrm{qN}_{\mathrm{s}}$ increased significantly compared with control cultures, showing a strong photo-inhibition of PSII under $\mathrm{N}$ deprivation. On the contrary, in $\mathrm{P}$-limited cultures, $\mathrm{qN}_{\mathrm{s}}$ remained unaffected, while $\mathrm{qN}_{\mathrm{i}}$ increased significantly. $\mathrm{qN}_{\mathrm{i}}$ is the main component in amplitude, it is triggered by lumen acidification during the high-light period, and relies on xanthophyll deepoxidation through the xanthophyll cycle (Roháček et al., 2014). The increase in $\mathrm{qN}_{\mathrm{i}}$ was in accordance with the results obtained from NPQ measurement, probably due to a malfunction of ATP synthase, which would be unable to drain protons out of the lumen. The excessive accumulation of protons would lead to an higher trans-thylakoid proton 
gradient, which in turn would activate the $\mathrm{pH}$-dependent diadinoxanthin deepoxidase (Roháček et al., 2014).

Hence, different acclimation mechanisms are implemented in P. tricornutum according to the nutrient limitation. Under N-limited stress, pigment contents decreased and PSII reaction centers partially closed, thus reducing the capture of light energy and inorganic carbon fixation. On the contrary, under P-limited stress, the photon absorption was less affected, while heat dissipation was enhanced to reduce the excess energy.

\section{Effect of $\mathbf{N}$ and $\mathbf{P}$ limitations on carbon partitioning}

Cellular carbon (C), soluble protein, carbohydrate and neutral lipid contents were measured throughout the cultures. Under N-limited conditions, the reduced photosynthetic rate led to weak carbon fixation, highlighted by the cellular $\mathrm{C}$ content remaining low (Fig. 2A). There was a significant decrease of soluble protein content per unit cell $\mathrm{C}$ after the exponential growth phase (Fig. 5A), due to a reduction of nitrogenous compound biosynthesis and, according to Alipanah et al. (2015) and Levitan et al. (2015), an accelerated degradation of proteins and amino acids. Protein degradation might provide both the reducing power NADH and the precursor of acetyl-CoA for fatty acid biosynthesis (Ge et al., 2014). The lowest protein value was recorded at the late stationary phase.

Diatoms store energy either as lipids or as chrysolaminarin (Kroth et al., 2008). Under N-limited conditions, the soluble carbohydrate (mainly chrysolaminarin) content per unit cell $\mathrm{C}$ was significantly higher during the stationary than during the exponential growth phase (Fig. 5B), suggesting that carbohydrate accumulation was enhanced during $\mathrm{N}$ deprivation. The highest value was recorded at the early stationary phase. The 
maximum carbohydrate content occurred prior to maximum neutral lipid accumulation (Fig. 5B-C), as it has been reported in previous studies (Li et al., 2011; Mus et al., 2013), suggesting that carbohydrates were used as the primary form energy storage and neutral lipids as secondary storage (Da Costa et al., 2017). The decrease of carbohydrate content per unit cell $\mathrm{C}$ during the late stationary phase suggests a conversion of carbohydrates to neutral storage lipid. The greatest neutral lipid increase was measured at late stationary phase. We can hypothesize that the carbon produced from the breakdown and interconversion of essential cellular compounds was directed to lipid synthesis (Valenzuela $e t$ al., 2012; Yang et al., 2013).

By contrast, in P-limited cells, a progressive accumulation of $\mathrm{C}$ was observed during the stationary phase (Fig. 2A), although the photosynthetic intensity per unit cell $\mathrm{C}$ was not significantly different from that of N-limited cells (Fig. 4A). This enhanced C accumulation could be the result of phosphoenolpyruvate carboxylase (PEPC) activity as it was reported in a green alga (Theodorou et al., 1990). This enzyme also releases $\mathrm{P}$ from phosphoenolpyruvate. However, this $\mathrm{C}$ accumulation did not lead to an increase in protein content. Moreover, the similar evolution of protein content per unit cell C in P-limited cultures compared with N-limited ones (Fig. 5A) indicates that the partitioning of carbon to proteins was also extremely inhibited under $\mathrm{P}$ deprivation. This inhibition might be related to an overall constraint on RNA and ATP synthesis (Yang et al., 2014; Feng et al., 2015; Dyhrman, 2016; Mühlroth et al., 2017).

Under P-limited conditions, carbohydrate accumulation showed a greater increase than in the control, although this was less intensive per unit cell $\mathrm{C}$ than in $\mathrm{N}$-limited cultures (Fig. 5B). In P. tricornutum and in another diatom Thalassiosira pseudonana, previous studies have reported an up-regulation of chrysolaminarin degradation-related 
enzyme at both transcript and protein levels during P depletion (Dyhrman et al., 2012; Yang et al., 2014; Cruz de Carvalho et al., 2016; Brembu et al., 2017). Our study did not examine the excretion of extracellular polysaccharides (ECPS); however, Abdullahi et al. (2006) have shown that $\mathrm{P}$ limitation favors ECPS production in P. tricornutum. In addition, Yang et al. (2014) measured an elevation of the Krebs cycle in P. tricornutum under P deprivation, suggesting that energy metabolism is favored over chrysolaminarin accumulation. The fixed carbon would mainly be engaged in energy metabolism, which mediates the formation of acetyl-CoA and $\mathrm{NADH}$, and then towards fatty acid biosynthesis.

In P-limited cells, neutral lipid content per cell on day 7 was about twice that found in N-limited cultures at the same time, and about 8.7 times higher than in day-2 control cells (data not shown). Interestingly, the partitioning of carbon to neutral lipids appeared to be very similar to that in N-limited culture as they shared the same value of neutral lipid content per unit cell $\mathrm{C}$ throughout the cultures (Fig. 5C). These results suggest a similar "push" scenario under N- or P-limited conditions, in which neutral lipid accumulation during stationary phase could allow excess carbon and reductive power to be consumed when the relative growth rate is weak or null (Valenzuela et al., 2012). This neutral lipid accumulation provides for long-term energy storage.

\section{Effect of $\mathbf{N}$ and $\mathrm{P}$ limitations on lipid metabolism}

Total lipid content followed a similar trend to that of neutral lipids (Fig. 5D), since neutral lipids were the predominant component of total lipids under $\mathrm{N}$ and $\mathrm{P}$ - limitation. Due to cell growth inhibition, the partitioning of carbon to membrane polar lipids was reduced. Increasing numbers of studies indicate that enhanced neutral lipid accumulation involves 
a combination of de novo synthesis pathways and the recycling of glycerolipids (Simionato et al., 2013; Martin et al., 2014; Yang et al., 2014; Abida et al., 2015; Alipanah et al., 2015; Popko et al., 2016; Mühlroth et al., 2017), while membrane polar lipids undergo a broad remodeling depending on the nature of the nutrient deprivation ( $\mathrm{Li}$ et al., 2014; Abida et al., 2015; Cañavate et al., 2017a, b; Mühlroth et al., 2017). In the present study, we analyzed the lipid profile of $P$. tricornutum, and showed the existence of monogalactosyldiacylglycerol (MGDG), digalactosyldiacylglycerol (DGDG), sulfoquinovosyldiacylglycerol (SQDG), and phosphatidylglycerol (PG) (results not shown), which are known to be the main lipids of the photosynthetic membranes (Li et al., 2014; Abida et al., 2015; Brembu et al., 2017). Phosphatidylcholine (PC), lysophosphatidylcholine (lyso-PC), phosphatidylinositol (PI), phosphatidylethanolamine (PE), together with the betaine lipids: DGTA, DGTS and an unknown lyso-betaine lipid (lyso-BL), which are the major lipids of the non-plastidial membranes, were also highlighted.

Our results revealed slight increases of the mRNA expression of enzymes involved in TAG assembly in both $\mathrm{N}$ - and P-limited cultures (Fig. 6A-B). The genes encoding glycerol-3-phosphate-O-acyltransferase (GPAT) were weakly up-regulated and only one of the five isoforms of 1-acyl-sn-glycerol-3-phosphate acyltransferase (AGPAT) was up-expressed. These two enzymes transfer two acyl-CoAs to glycerol-3-phosphate (G3P) to form phosphatidic acid (PA) that is then dephosphorylated by phosphatidic acid phosphatase (PAP) to diacylglycerol (DAG). One of the putative PAP genes (PAP2) was up-regulated on day 7 in N-limited culture, while two PAP genes displayed a mRNA increase in P-limited culture. DAG is an intermediate lipid at the crossroads of different 
biosynthesis pathways. The different enzymes catalyzing the subsequent pathways will then lead to either TAG or membrane lipid synthesis (Fig. 6).

The last step of TAG synthesis is catalyzed by diacylglycerol O-acyltransferase (DGAT), which transfers the third acyl-CoA to DAG (Lung \& Weselake, 2006). During $\mathrm{N}$ limitation, three out of the six DGAT gene isoforms were up-regulated (Fig. 6A). Likewise, during P limitation, four out of the different DGAT genes were up-regulated (Fig. 6B). In addition, TAG synthesis might also use phospholipids as acyl donors by phospholipid-diacylglycerol acyltransferase (PDAT) (Yoon et al., 2012; Alipanah et al., 2015; Cruz de Carvalho et al., 2016). Only one putative gene encoding PDAT was induced in the N-limited culture (PDAT1: 4.1 and 4.3-fold on day 4 and day 7, respectively, Fig. 6A), while both isoforms were strongly up-regulated in P-limited culture (PDAT1: 5.2 and 6.3-fold on day 4 and day 7; PDAT2: 4.9 and 6.1-fold on day 4 and day 7, respectively, Fig. 6B), especially during the late stationary phase. The upregulation of PDAT could favor TAG production via phospholipid reshuffling during $\mathrm{P}$ deprivation.

In chloroplasts, glycolipids are synthesized by transferring glucose or galactose moieties onto the membrane lipid DAG (Li-Beisson et al., 2010). When total glycolipid content is normalized per unit of cell $\mathrm{C}$, there is no difference between the three culture conditions until day 4 , then glycolipid content decreased during the stationary growth phase in nutrient limited cells compared with control cells (Fig. 7A). During N limitation, a predicted MGDG synthase (MGD1) and SQDG synthase 2 (SQD2) were downregulated (Fig. 6A). These down-regulations are consistent with the decrease in glycolipid content normalized per cell (data not shown). This decrease was mainly due to the reduction of MGDG (Fig. 7A-1), and a reduced MGDG:DGDG ratio was observed (data 
not shown), indicating a reorganization of the thylakoid membranes. Indeed, similar results have been obtained by other researchers (Abida et al., 2015; Popko et al., 2016), the reduced MGDG:DGDG ratio often signifying impaired photosynthesis (Boudière et al., 2014; Abida et al., 2015), whereas the increase in DGDG (Fig. 7A-2) might contribute to the protection of photosynthetic membrane integrity (Abida et al., 2015). Under $\mathrm{P}$ deprivation, the thylakoid membrane composition was largely maintained as it was observed by Iwai et al. (2014). One of the predicted MGDG synthases (MGD3) was upregulated, while SQD2 was not induced (Fig. 6B). However, the lipid analysis showed a significant increase of SQDG content per cell, while MGDG content remained constant (data not shown). Although there was no significant difference of SQDG content per unit cell C compared with control cells (Fig. 7A-3), the increase of SQDG proportion in thylakoid membranes, in agreement with previous studies (Abida et al., 2015; Shemi et al., 2016; Cañavate et al., 2017a), could partly compensate for the lack of PG in the plastids (Jouhet et al., 2009).

Phospholipids were not affected by N-limitation (Fig. 7A), but they were almost completely eliminated under P-limitation (Fig. 7B). Phospholipid content per unit cell C decreased by $92 \%$ on day 4 and by $96 \%$ on day 7 relative to values in the control cultures. Consequently, the breakdown of phospholipids allowed the cells to obtain enough $\mathrm{P}$ to survive and even to grow in low-P conditions. Interestingly, no downregulation of the genes encoding enzymes involved in phospholipid biosynthesis was observed (Fig. 6B). Indeed, one of the putative phosphatidate cytidylyltransferases (CDS) was up-regulated during P starvation. A similar result was reported in Nannochloropsis oceanica, suggesting that phospholipids might be continuously synthesized under $\mathrm{P}$ limitation (Mühlroth et al., 2017). They would not directly participate in membrane lipid 
construction but indirectly through their degradation (Yang et al., 2014) or acyl-editing mechanisms (catalyzed by PDAT) supply precursors for P-free lipid synthesis (Mühlroth et al., 2017).

Betaine lipids (BL, Fig. 7C) are considered to be the major replacement compounds for phospholipids in non-plastidial membranes (Wilhelm et al., 2006; Abida et al., 2015; Cañavate et al., 2016, 2017a, b; Shemi et al., 2016; Mühlroth et al., 2017). The N-limited cells showed similar BL content compared with control cells. The mRNA expression of the putative DGTA synthesis enzyme (BTA) was not induced (Fig. 6A). On the contrary, under P limitation, the betaine lipid content (Fig. 7C) counterbalanced the decrease in phospholipid content (Fig. 7B). The DGTA content per unit of cell C was increased up to 20 times on day 7 compared with day-2 control cells (Fig. 7C-1), while the lyso-BL content was increased up to 5.8 times on day 7 compared with day- 2 control cells (Fig 7C-2). The concomitant increase in DGTA and decrease in phospholipids is in agreement with previous reports (Abida et al., 2015; Cañavate et al., 2017a), suggesting that the replacement of phospholipids by DGTA is an essential metabolic reorientation in P. tricornutum under $\mathrm{P}$ deprivation. The phospholipid substitution in the plasmalemma could enable the cells to continue to grow during P deprivation. Indeed, the transcriptomic analysis (Fig. 6B) indicated a strong and rapid expression of the putative DGTA synthesis enzyme (BTA: 4.2, 9.6 and 8.2-fold on day 2, day 4 and day 7 compared with day-2 control cells, respectively) under P deprivation, suggesting that the exact timing of initial lipid remodeling might even be before day 2 . At that time, according to culture modeling (Droop, 1973; Bougaran et al., 2010), the cellular internal P quota should be kept at a high level to support the high growth rate. Therefore, we suggest that the DGTA synthesis might be triggered by the external $\mathrm{P}$ concentration, which had decreased to an 
undetectable level by day 2. A much stronger upregulation was previously reported in another strain of P. tricornutum under P depletion (Cruz de Carvalho et al., 2016), confirming that membrane remodeling in this species is directly related to $\mathrm{P}$ limitation and is tightly regulated. There was a decline in DGTS content when P limitation was stronger (Fig. 7C-3), suggesting that DGTS might not be an important substitute for phospholipids; however, it might be a major source for TAG synthesis, as suggested by Popko et al. (2016).

The fatty acid (FA) composition of each major lipid fraction in P. tricornutum during the early stationary phase under $\mathrm{N}$ and P-limited conditions (day 4) is shown in Fig. 8. The major FA species of neutral lipids were palmitic acid (C16:0), palmitoleic acid (C16:1n-7) and eicosapentaenoic acid (EPA, C20:5n-3) (Fig. 8A). The most notable change was the increase of $\mathrm{C} 16: 0$ and $\mathrm{C} 16: 1 \mathrm{n}-7$ levels in the neutral lipids. C16:0 and C16:1n-7 are normally newly synthesized FA species. Their increase suggests that the accumulation of TAG triggered by nutrient limitations was mainly from the de novo FA synthesis pathway, as previously mentioned (Simionato et al., 2013; Martin et al., 2014; Abida et al., 2015). There was a slight increase in C16:1n-7 relative to C16:0 during Plimitation, suggesting an enhanced $\Delta 9$ desaturation. As a consequence of a much higher C16:0 and C16:1n-7 accumulation, the proportion of EPA in the fraction of neutral lipids dropped under $\mathrm{N}$ - and P-limited conditions (Fig. 8A). However, no increase was observed in the EPA level per cell in N-limited cultures, but a 1.6-fold increase was observed in the P-limited cells (data not shown). Overall, more long chain polyunsaturated fatty acids (LC-PUFAs) were significantly higher under P-deprivation than in the control and N-limited cultures (data not shown). These LC-PUFAs in TAG 
might mainly be derived from the recycling of membrane polar lipids (Mühlroth et al., 2013; Mus et al., 2013; Remmers et al., 2017).

Even though the amount of chloroplast glycolipids changed under $\mathrm{N}$ - and Plimitations, their FA composition appeared to be unaltered (Fig. 8B) and could contribute to maintain efficient photosynthetic activity. In the phospholipids and betaine lipids, the EPA proportion increased with both limitations (Fig. 8C). A similar increase was reported by Popko et al. (2016) in the same strain, the authors suggested that EPA was transferred from glycolipids to phospholipids and betaine lipids. On the contrary, a decrease of C22 FA was recorded in both $\mathrm{N}$ - and P-limited conditions, especially of docosahexaenoic acid (DHA, C22:6n-3). The decrease of LC-PUFAs might contribute to TAG synthesis as we mentioned before, or be the result of a weaker activity of the $\Delta 5$-elongase, this enzyme is the major bottleneck that allows EPA to be converted into longer chain FA (Hamilton et al., 2014). In addition, the replacement of phospholipids by betaine lipids under $\mathrm{P}$ starvation led to a decrease in oleic acid (C18:1n-9) concomitantly with the increase of linoleic acid (C18:2n-6), $\alpha$-linolenic acid (C18:3n-3) and stearidonic acid (C18:4n-3), suggesting an enhanced desaturation of FA, probably related to the cellular accumulation of NADH.

\section{Conclusion}

This study focused on the responses of $P$. tricornutum to nutrient limitation. It compared the impact of $\mathrm{N}$ and $\mathrm{P}$ limitations on growth, photosynthesis, metabolic reorientation and, especially, lipid profile remodeling, revealing the different acclimation strategies. Under $\mathrm{N}$ limitation, pigment contents were reduced and PSII centers partially inhibited, light energy absorption and utilization decreased, as did carbon fixation. The breakdown and 
inter-conversion of essential cellular compounds contributed to TAG accumulation. Under P limitation, the light harvesting complexes seemed to be less hampered. The mechanisms of non-photochemical quenching were more active to keep the balance between energy absorption and photochemical utilization. $\mathrm{C}$ accumulation was promoted in P-limited stationary phase cells that ultimately fueled the allocation of carbon fluxes to TAG accumulation without massive degradation of cellular N-containing compounds.

In addition, the substitution of phospholipids with betaine lipids seemed to be a P-specific acclimation strategy, and was largely regulated at the mRNA expression level. The gene encoding DGTA synthesis enzyme was highly expressed under P limitation, and might be triggered by external $\mathrm{P}$ concentration. The signal transduction chain is still unknown. The phospholipid biosynthesis pathway might not be completely inhibited; these phospholipids could be immediately shifted via enhanced phospholipid-recycling mechanisms. Our results provide an overall lipid profile of $P$. tricornutum at different growth phases and under $\mathrm{N}$ and $\mathrm{P}$ limitations. A MS/MS structural identification is still needed to distinguish additional lipid classes and to determine the FA composition (sn-1 and $s n$-2 positions), in order to better understand the FA trafficking involved in the lipid class reshuffling.

\section{Acknowledgements}

This work was funded by the region Pays de la Loire (France) through the "Atlantic MicroAlgae" contract. The authors thank Adrien Cadoudal and Léa Mustière, Master's students, for their technical assistance, Anis Limami of Angers University for his constructive discussions, Helen McCombie-Boudry for improving the English language and anonymous reviewers for their constructive criticisms. 


\section{Figure captions}

Fig. 1. Growth of P. tricornutum under control (NP), N-limited (N-) or P-limited (P-) conditions over 9 days in batch cultures (Mean \pm S.D., $n=5$ ). (A) Semi-log plot of growth curves (cell density $\mathrm{ml}^{-1}$ ) and specific growth rate $\left(\mathrm{d}^{-1}\right)$ in the insert, (B) Dissolved $\mathrm{NO}_{3}^{-}$ concentration $(\mathrm{mM})$ and $\mathrm{P}$ concentration $(\mu \mathrm{M})$ in NP cultures, $(\mathrm{C})$ Dissolved $\mathrm{NO}_{3}{ }^{-}$ concentration $(\mathrm{mM})$ and $\mathrm{P}$ concentration $(\mu \mathrm{M})$ in $\mathrm{N}$-limited cultures, (D) Dissolved $\mathrm{NO}_{3}{ }^{-}$ concentration $(\mathrm{mM})$ and $\mathrm{P}$ concentration $(\mu \mathrm{M})$ in P-limited cultures.

Fig. 2. Particulate carbon and nitrogen in P. tricornutum grown under control (NP), Nlimited (N-) or P-limited (P-) conditions over 9 days in batch cultures. (Mean \pm S.D., $\mathrm{n}=$ 3). (A) Carbon content per cell (pg cell $\left.{ }^{-1}\right)$, (B) Nitrogen content per unit cell carbon (g/g).

Fig. 3. Pigment contents of $P$. tricornutum grown under control (NP), N-limited (N-) or P-limited (P-) conditions (Mean \pm S.D., $\mathrm{n}=3$, different letters indicate significant $(\mathrm{p}<$ 0.05) differences at each culture day). (A) Chl $a$ content per unit cell carbon (mg/g), (B) Chl c content per unit cell carbon (mg/g), (C) Fucoxanthin content per unit cell carbon $(\mathrm{mg} / \mathrm{g})$.

Fig. 4. Physiological parameters of P. tricornutum grown under control (NP), N-limited $(\mathrm{N}-)$ or $\mathrm{P}$-limited $(\mathrm{P}-)$ conditions. Different letters indicate significant $(\mathrm{p}<0.05)$ differences at each culture day (Mean \pm S.D., $n=3$ ). (A) Gross photosynthesis per unit cell carbon ( $\mu \mathrm{mol} \mathrm{O} 2 / \mathrm{h} / \mathrm{mg} \mathrm{C})$, (B) Maximum photochemical efficiency of PSII $\left(\mathrm{F}_{\mathrm{v}} / \mathrm{F}_{\mathrm{m}}\right)$, (C) Effective photochemical efficiency of PSII ( $\left.\Phi_{\text {II }}\right)$ under $300 \mu \mathrm{mol}$ photons $\mathrm{m}^{-2} \mathrm{~s}^{-1}$, (D) Non-photochemical quenching (NPQ) under $300 \mu \mathrm{mol}$ photons $\mathrm{m}^{-2} \mathrm{~s}^{-1}$, (E) Proportions of $\mathrm{qN}_{\mathrm{f}}, \mathrm{qN}_{\mathrm{i}}$ and $\mathrm{qN}_{\mathrm{s}}$ in $\mathrm{qN}$ after a high irradiance $\left(1000 \mu \mathrm{mol}\right.$ photons $\left.\mathrm{m}^{-2} \mathrm{~s}^{-1}\right)$ on day 4. 
Fig. 5. Proximate biochemical composition of $P$. tricornutum grown under control (NP), $\mathrm{N}$-limited (N-) or P-limited (P-) conditions over 9 days in batch cultures. (Mean \pm S.D., $\mathrm{n}=3$ ). (A) Soluble protein content per unit cell carbon (g/g), (B) Soluble carbohydrate content per unit cell carbon (g/g), (C) Fluorescence of microalgae cells stained with Nile red per unit cell carbon $\left(\mu \mathrm{g} \mathrm{C}^{-1}\right)$ as measurements of neutral lipid content, (D) Total lipid content per unit cell carbon $(\mathrm{g} / \mathrm{g})$.

Fig. 6. Transcriptional fold changes, from triplicate cultures, under (A) N-limited (N-) or (B) P-limited (P-) conditions of 28 genes/isogenes coding for 10 enzymes involved in TAG and membrane lipid biosynthetic pathways in $P$. tricornutum. Colored squares indicate the regulation pattern on days 2, 4 and 7 (red, upregulated; green, downregulated). For both N- and P-limited conditions, day-2 control cultures were used as calibrator. Asterisks indicate significant regulation compared with day-2 control cultures $(\mathrm{p}<0.01$ and $\left[\log _{2}\right.$ fold $>1$ or $\log _{2}$ fold $\left.<-1\right]$ or $p<0.05$ and $\left[\log _{2}\right.$ fold $>2$ or $\log _{2}$ fold $\left.<-2\right]$ ). See Supplementary Table S1 for correspondence between gene abbreviations and protein ID. CDP-DAG, cytidine diphosphate diacylglycerol; DAG, diacylglycerol; DGDG, digalactosyldiacylglycerol; G3P, glycerol-3-phosphate; LPA, lysophosphatidic acid; MGDG, monogalactosyldiacylglycerol; PA, phosphatidic acid; PC, phosphatidylcholine; PE, phosphatidylethanolamine; PG, phosphatidylglycerol; PI, phosphatidylinositol; SQDG, sulfoquinovosyldiacylglycerol; TAG, triacylglycerol.

Fig. 7. Quantitative analysis of lipid classes extracted from P. tricornutum grown under control (NP), N-limited (N-) or P-limited (P-) conditions. Different letters indicate significant $(\mathrm{p}<0.05)$ differences at each culture day (Mean \pm S.D., $n=3$ ). (A) Glycolipids 
(GL): A-1. MGDG, monogalactosyldiacylglycerol, A-2. DGDG, digalactosyldiacylglycerol, $\quad$ A-3. SQDG, sulfoquinovosyldiacylglycerol; $\quad$ (B) Phospholipids (PL): B-1. Lyso-PC, B-2. PC, phosphatidylcholine, B-3. PI, phosphatidylinositol, B-4. PE, phosphatidylethanolamine and PG, phosphatidylglycerol; (C) Betaine lipids (BL): C-1. DGTA, diacylglycerylhydroxymethyltrimethyl- $\beta$-alanine, C-2. lyso-BL, C-3. DGTS, diacylglyceroltrimethylhomoserine.

Fig. 8. Fatty acid distribution in three main fractions of lipids extracted from $P$. tricornutum grown under control (NP), N-limited (N-) or P-limited (P-) conditions on day 4. Different letters indicate significant ( $\mathrm{p}<0.05$ ) differences (Mean \pm S.D., $n=3$ ). (A) Fatty acid distribution in neutral lipids, (B) Fatty acid distribution in glycolipids, (C) Fatty acid distribution in phospholipids and betaine lipids. Fatty acids: C14:0, myristic acid; C14:1n-5, myristoleic acid; C16:0, palmitic acid; C16:1n-7, palmitoleic acid; C16:2n-6, hexadecadienoic acid; C16:3n-4, hexadecatrienoic acid, C18:0, stearic acid; C18:1n-9, oleic acid; C18:2n-6, linoleic acid; C18:3n-3, $\alpha$-linolenic acid; C18:4n-3, stearidonic acid; C20:2n-6, eicosadienoic acid; C20:4n-6, arachidonic acid; C20:5n-3, eicosapentaenoic acid; C22:4n-6, docosatetraenoic acid; C22:5n-3, docosapentaenoic acid; C22:6n-3, docosahexaenoic acid. 


\section{Supplementary data}

Supplementary Table. S1. List of enzymes and related genes analyzed by real-time qPCR and their respective primers.

Supplementary Fig. S1. Cell volume $\left(\mu \mathrm{m}^{3}\right)$ of $P$. tricornutum grown under control (NP), $\mathrm{N}$-limited (N-) or P-limited (P-) conditions in batch cultures. The width of spindle-shaped figures is correlated with the distribution of the cell volume. The black line indicates the average size. ( $\mathrm{n}>60$ for each culture medium).

Supplementary Fig. S2. Slow Chl $a$ fluorescence induction kinetics of $P$. tricornutum grown under (A-1) control (NP), (B-1) N-limited (N-) or (C-1) P-limited (P-) conditions on day 4 measured under a high actinic irradiance $\left(1000 \mu \mathrm{mol}\right.$ photons $\left.\mathrm{m}^{-2} \mathrm{~s}^{-1}\right)$, and their respective qN relaxation kinetics after switching the actinic light off ((A-2) control (NP) ; (B-2) N-limited (N-) ; (C-2) P-limited (P-)). 


\section{References}

Abdullahi, A.S., Underwood, G.J.C. \& Gretz, M.R. (2006). Extracellular matrix assembly in diatoms (Bacillariophyceae). V. Environmental effects on polysaccharide synthesis in the model diatom, Phaeodactylum tricornutum. Journal of Phycology, 42: $363-378$.

Abida, H., Dolch, L.-J., Meï, C., Villanova, V., Conte, M., Block, M.A., Finazzi, G., Bastien, O., Tirichine, L., Bowler, C., Rébeillé, F., Petroutsos, D., Jouhet, J. \& Maréchal, E. (2015). Membrane glycerolipid remodeling triggered by nitrogen and phosphorus starvation in Phaeodactylum tricornutum. Plant Physiology, 167: $118-136$.

Alipanah, L., Rohloff, J., Winge, P., Bones, A.M. \& Brembu, T. (2015). Whole-cell response to nitrogen deprivation in the diatom Phaeodactylum tricornutum. Journal of Experimental Botany, 66: 6281-6296.

Alipanah, L., Winge, P., Rohloff, J., Najafi, J., Brembu, T. \& Bones, A.M. (2018). Molecular adaptations to phosphorus deprivation and comparison with nitrogen deprivation responses in the diatom Phaeodactylum tricornutum. PLoS One, 13: e0193335.

American Public Health Association (1992). APHA Method 4500-NO3: Standard Methods for the Examination of Water and Wastewater.

Armbrust, E.V., Berges, J.A., Bowler, C., Green, B.R., Martinez, D., Putnam, N.H., Zhou, S., Allen, A.E., Apt, K.E., Bechner, M., Brzezinski, M.A., Chaal, B.K., Chiovitti, A., Davis, A.K., Demarest, M.S., Detter, J.C., Glavina, T., Goodstein, D., Hadi, M.Z., Hellsten, U., Hildebrand, M., Jenkins, B.D., Jurka, J., Kapitonov, V.V., Kröger, N., Lau, W.W.Y., Lane, T.W., Larimer, F.W., Lippmeier, J.C., Lucas, S., 
Medina, M., Montsant, A., Obornik, M., Parker, M.S., Palenik, B., Pazour, G.J., Richardson, P.M., Rynearson, T.A., Saito, M.A., Schwartz, D.C., Thamatrakoln, K., Valentin, K., Vardi, A., Wilkerson, F.P. \& Rokhsar, D.S. (2004). The genome of the diatom Thalassiosira pseudonana: Ecology, evolution, and metabolism. Science, 306: 79-86.

Beale, S.I. \& Appleman, D. (1971). Chlorophyll synthesis in Chlorella: Regulation by degree of light limitation of growth. Plant Physiology, 47: 230-235.

Bligh, E.G. \& Dyer, W.J. (1959). A rapid method of total lipid extraction and purification. Canadian Journal of Biochemistry and Physiology, 37: 911-917.

Boudière, L., Michaud, M., Petroutsos, D., Rébeillé, F., Falconet, D., Bastien, O., Roy, S., Finazzi, G., Rolland, N., Jouhet, J., Block, M.A. \& Maréchal, E. (2014). Glycerolipids in photosynthesis: composition, synthesis and trafficking. Biochimica et Biophysica Acta - Bioenergetics, 1837: 470-480.

Bougaran, G., Bernard, O. \& Sciandra, A. (2010). Modeling continuous cultures of microalgae colimited by nitrogen and phosphorus. Journal of Theoretical Biology, 265: $443-454$.

Bowler, C., Allen, A.E., Badger, J.H., Grimwood, J., Jabbari, K., Kuo, A., Maheswari, U., Martens, C., Maumus, F., Otillar, R.P., Rayko, E., Salamov, A., Vandepoele, K., Beszteri, B., Gruber, A., Heijde, M., Katinka, M., Mock, T., Valentin, K., Verret, F., Berges, J.A., Brownlee, C., Cadoret, J.-P., Chiovitti, A., Choi, C.J., Coesel, S., Martino, A.D., Detter, J.C., Durkin, C., Falciatore, A., Fournet, J., Haruta, M., Huysman, M.J.J., Jenkins, B.D., Jiroutova, K., Jorgensen, R.E., Joubert, Y., Kaplan, A., Kröger, N., Kroth, P.G., Roche, J.L., Lindquist, E., Lommer, M., Martin-Jézéquel, V., Lopez, P.J., Lucas, S., Mangogna, M., 
McGinnis, K., Medlin, L.K., Montsant, A., Secq, M.-P.O., Napoli, C., Obornik, M., Parker, M.S., Petit, J.-L., Porcel, B.M., Poulsen, N., Robison, M., Rychlewski, L., Rynearson, T.A., Schmutz, J., Shapiro, H., Siaut, M., Stanley, M., Sussman, M.R., Taylor, A.R., Vardi, A., Dassow, P. von, Vyverman, W., Willis, A., Wyrwicz, L.S., Rokhsar, D.S., Weissenbach, J., Armbrust, E.V., Green, B.R., Van de Peer, Y. \& Grigoriev, I.V. (2008). The Phaeodactylum genome reveals the evolutionary history of diatom genomes. Nature, 456: 239-244.

Bradford, M.M. (1976). A rapid and sensitive method for the quantitation of microgram quantities of protein utilizing the principle of protein-dye binding. Analytical Biochemistry, 72: 248-254.

Brembu, T., Mühlroth, A., Alipanah, L. \& Bones, A.M. (2017). The effects of phosphorus limitation on carbon metabolism in diatoms. Philosophical Transactions of the Royal Society B, 372: 20160406.

Brooks, A. (1986). Effects of phosphorus nutrition on ribulose-1,5-bisphosphate carboxylase activation, photosynthetic quantum yield and amounts of some calvin-cycle metabolites in spinach leaves. Functional Plant Biology, 13: 221237.

Cañavate, J.P., Armada, I. \& Hachero-Cruzado, I. (2017a). Interspecific variability in phosphorus-induced lipid remodelling among marine eukaryotic phytoplankton. New Phytologist, 213: 700-713.

Cañavate, J.P., Armada, I. \& Hachero-Cruzado, I. (2017b). Aspects of phosphorus physiology associated with phosphate-induced polar lipid remodelling in marine microalgae. Journal of Plant Physiology, 214: 28-38. 
Cañavate, J.P., Armada, I., Ríos, J.L. \& Hachero-Cruzado, I. (2016). Exploring occurrence and molecular diversity of betaine lipids across taxonomy of marine microalgae. Phytochemistry, 124: 68-78.

Chen, W., Zhang, C., Song, L., Sommerfeld, M. \& Hu, Q. (2009). A high throughput Nile red method for quantitative measurement of neutral lipids in microalgae. Journal of Microbiological Methods, 77: 41-47.

Chisti, Y. (2007). Biodiesel from microalgae. Biotechnology Advances, 25: 294-306.

Chylla, R.A. \& Whitmarsh, J. (1989). Inactive photosystem II complexes in leaves: turnover rate and quantitation. Plant Physiology, 90: 765-772.

Cruz de Carvalho, M.H., Sun, H.-X., Bowler, C. \& Chua, N.-H. (2016). Noncoding and coding transcriptome responses of a marine diatom to phosphate fluctuations. New Phytologist, 210: 497-510.

Curtis, B.A., Tanifuji, G., Burki, F., Gruber, A., Irimia, M., Maruyama, S., Arias, M.C., Ball, S.G., Gile, G.H., Hirakawa, Y., Hopkins, J.F., Kuo, A., Rensing, S.A., Schmutz, J., Symeonidi, A., Elias, M., Eveleigh, R.J.M., Herman, E.K., Klute, M.J., Nakayama, T., Oborník, M., Reyes-Prieto, A., Armbrust, E.V., Aves, S.J., Beiko, R.G., Coutinho, P., Dacks, J.B., Durnford, D.G., Fast, N.M., Green, B.R., Grisdale, C.J., Hempel, F., Henrissat, B., Höppner, M.P., Ishida, K.-I., Kim, E., Kořený, L., Kroth, P.G., Liu, Y., Malik, S.-B., Maier, U.G., McRose, D., Mock, T., Neilson, J.A.D., Onodera, N.T., Poole, A.M., Pritham, E.J., Richards, T.A., Rocap, G., Roy, S.W., Sarai, C., Schaack, S., Shirato, S., Slamovits, C.H., Spencer, D.F., Suzuki, S., Worden, A.Z., Zauner, S., Barry, K., Bell, C., Bharti, A.K., Crow, J.A., Grimwood, J., Kramer, R., Lindquist, E., Lucas, S., Salamov, A., McFadden, G.I., Lane, C.E., Keeling, P.J., Gray, M.W., Grigoriev, I.V. \& Archibald, J.M. 
(2012). Algal genomes reveal evolutionary mosaicism and the fate of nucleomorphs. Nature, 492: 59-65.

Da Costa, F., Le Grand, F., Quéré, C., Bougaran, G., Cadoret, J.P., Robert, R. \& Soudant, P. (2017). Effects of growth phase and nitrogen limitation on biochemical composition of two strains of Tisochrysis lutea. Algal Research, 27: 177-189.

Deschamps, P. \& Moreira, D. (2012). Reevaluating the green contribution to diatom genomes. Genome Biology and Evolution, 4: 683-688.

Dittmer, J.C. \& Lester, R.L. (1964). A simple, specific spray for the detection of phospholipids on thin-layer chromatograms. Journal of Lipid Research, 5: 126127.

Droop, M.R. (1973). Some thoughts on nutrient limitation in algae. Journal of Phycology, 9: $264-272$.

Dubois, M., Gilles, K., Hamilton, J.K., Rebers, P.A. \& Smith, F. (1951). A colorimetric method for the determination of sugars. Nature, 168: 167.

Dyhrman, S.T. (2016). Nutrients and their acquisition: Phosphorus physiology in microalgae. In The Physiology of Microalgae, Developments in Applied Phycology (Borowitzka, M.A., Beardall, J. \& Raven, J.A., editors), 155-183. Springer, Cham.

Dyhrman, S.T., Jenkins, B.D., Rynearson, T.A., Saito, M.A., Mercier, M.L., Alexander, H., Whitney, L.P., Drzewianowski, A., Bulygin, V.V., Bertrand, E.M., Wu, Z., Benitez-Nelson, C. \& Heithoff, A. (2012). The transcriptome and proteome of the diatom Thalassiosira pseudonana reveal a diverse phosphorus stress response. PLoS One, 7: e33768. 
Falkowski, P.G. \& Raven, J.A. (2007). Aquatic Photosynthesis. Princeton University Press.

Feng, T.-Y., Yang, Z.-K., Zheng, J.-W., Xie, Y., Li, D.-W., Murugan, S.B., Yang, W.-D., Liu, J.-S. \& Li, H.-Y. (2015). Examination of metabolic responses to phosphorus limitation via proteomic analyses in the marine diatom Phaeodactylum tricornutum. Scientific Reports, 5: 10373.

Ge, F., Huang, W., Chen, Z., Zhang, C., Xiong, Q., Bowler, C., Yang, J., Xu, J. \& Hu, H. (2014). Methylcrotonyl-CoA carboxylase regulates triacylglycerol accumulation in the model diatom Phaeodactylum tricornutum. The Plant Cell, 26: 1681-1697.

Geider, R. \& La Roche, J. (2002). Redfield revisited: variability of C:N:P in marine microalgae and its biochemical basis. European Journal of Phycology, 37: 1-17.

Geider, R.J., La Roche, J., Greene, R.M. \& Olaizola, M. (1993). Response of the photosynthetic apparatus of Phaeodactylum tricornutum (Bacillariophyceae) to nitrate, phosphate, or iron starvation. Journal of Phycology, 29: 755-766.

Hamilton, M.L., Haslam, R.P., Napier, J.A. \& Sayanova, O. (2014). Metabolic engineering of Phaeodactylum tricornutum for the enhanced accumulation of omega-3 long chain polyunsaturated fatty acids. Metabolic Engineering, 22: 3-9.

Heydarizadeh, P., Boureba, W., Zahedi, M., Huang, B., Moreau, B., Lukomska, E., Couzinet-Mossion, A., Wielgosz-Collin, G., Martin-Jézéquel, V., Bougaran, G., Marchand, J. \& Schoefs, B. (2017). Response of CO2-starved diatom Phaeodactylum tricornutum to light intensity transition. Philosophical Transactions of the Royal Society B, 372: 20160396.

Huang, N., Siegel, M.M., Kruppa, G.H. \& Laukien, F.H. (1999). Automation of a Fourier transform ion cyclotron resonance mass spectrometer for acquisition, analysis, 
and e-mailing of high-resolution exact-mass electrospray ionization mass spectral data. Journal of the American Society for Mass Spectrometry, 10: 1166-1173.

Iwai, M., Ikeda, K., Shimojima, M. \& Ohta, H. (2014). Enhancement of extraplastidic oil synthesis in Chlamydomonas reinhardtii using a type-2 diacylglycerol acyltransferase with a phosphorus starvation-inducible promoter. Plant Biotechnology Journal, 12: 808-819.

Jacob, J. \& Lawlor, D.W. (1993). In vivo photosynthetic electron transport does not limit photosynthetic capacity in phosphate-deficient sunflower and maize leaves. Plant, Cell \& Environment, 16: 785-795.

Jouhet, J., Dubots, E., Maréchal, E. \& Block, M.A. (2009). Lipid trafficking in plant photosynthetic cells. In Lipids in Photosynthesis, Essential and Regulatory Functions (Wada, H. \& Murata, N., editors), 349-372. Springer, Dordrecht.

Kato, M., Sakai, M., Adachi, K., Ikemoto, H. \& Sano, H. (1996). Distribution of betaine lipids in marine algae. Phytochemistry, 42: 1341-1345.

Khozin-Goldberg, I. \& Cohen, Z. (2006). The effect of phosphate starvation on the lipid and fatty acid composition of the fresh water eustigmatophyte Monodus subterraneus. Phytochemistry, 67: 696-701.

Kroth, P.G., Chiovitti, A., Gruber, A., Martin-Jezequel, V., Mock, T., Parker, M.S., Stanley, M.S., Kaplan, A., Caron, L., Weber, T., Maheswari, U., Armbrust, E.V. \& Bowler, C. (2008). A Model for carbohydrate metabolism in the diatom Phaeodactylum tricornutum deduced from comparative whole genome analysis. PLoS One, 3: e1426.

Levitan, O., Dinamarca, J., Zelzion, E., Lun, D.S., Guerra, L.T., Kim, M.K., Kim, J., Van Mooy, B.A.S., Bhattacharya, D. \& Falkowski, P.G. (2015). Remodeling of 
intermediate metabolism in the diatom Phaeodactylum tricornutum under nitrogen stress. Proceedings of the National Academy of Sciences of the United States of America, 112: 412-417.

Li, S., Xu, J., Chen, J., Chen, J., Zhou, C. \& Yan, X. (2014). The major lipid changes of some important diet microalgae during the entire growth phase. Aquaculture, $\mathbf{4 2 8}$ 429: $104-110$.

Li, Y., Han, D., Sommerfeld, M. \& Hu, Q. (2011). Photosynthetic carbon partitioning and lipid production in the oleaginous microalga Pseudochlorococcum sp. (Chlorophyceae) under nitrogen-limited conditions. Bioresource Technology, Special Issue: Biofuels - II: Algal Biofuels and Microbial Fuel Cells, 102: 123129.

Li-Beisson, Y., Shorrosh, B., Beisson, F., Andersson, M.X., Arondel, V., Bates, P.D., Baud, S., Bird, D., DeBono, A., Durrett, T.P., Franke, R.B., Graham, I.A., Katayama, K., Kelly, A.A., Larson, T., Markham, J.E., Miquel, M., Molina, I., Nishida, I., Rowland, O., Samuels, L., Schmid, K.M., Wada, H., Welti, R., Xu, C., Zallot, R. \& Ohlrogge, J. (2010). Acyl-lipid metabolism. The Arabidopsis Book, 8: e0133.

Lin, S., Litaker, R.W. \& Sunda, W.G. (2016). Phosphorus physiological ecology and molecular mechanisms in marine phytoplankton. Journal of Phycology, 52: 1036.

Livak, K.J. \& Schmittgen, T.D. (2001). Analysis of relative gene expression data using real-time quantitative PCR and the 2- $\Delta \Delta \mathrm{CT}$ method. Methods, 25: 402-408.

Lung, S.-C. \& Weselake, R.J. (2006). Diacylglycerol acyltransferase: a key mediator of plant triacylglycerol synthesis. Lipids, 41: 1073-1088. 
Maeda, Y., Nojima, D., Yoshino, T. \& Tanaka, T. (2017). Structure and properties of oil bodies in diatoms. Philosophical Transactions of the Royal Society B, 372: 20160408.

Marsh, J.B. \& Weinstein, D.B. (1966). Simple charring method for determination of lipids. Journal of Lipid Research, 7: 574-576.

Martin, G.J.O., Hill, D.R.A., Olmstead, I.L.D., Bergamin, A., Shears, M.J., Dias, D.A., Kentish, S.E., Scales, P.J., Botté, C.Y. \& Callahan, D.L. (2014). Lipid profile remodeling in response to nitrogen deprivation in the microalgae Chlorella sp. (Trebouxiophyceae) and Nannochloropsis sp. (Eustigmatophyceae). PLoS One, 9: e103389.

Moore, C.M., Mills, M.M., Arrigo, K.R., Berman-Frank, I., Bopp, L., Boyd, P.W., Galbraith, E.D., Geider, R.J., Guieu, C., Jaccard, S.L., Jickells, T.D., Roche, J.L., Lenton, T.M., Mahowald, N.M., Marañón, E., Marinov, I., Moore, J.K., Nakatsuka, T., Oschlies, A., Saito, M.A., Thingstad, T.F., Tsuda, A. \& Ulloa, O. (2013). Processes and patterns of oceanic nutrient limitation. Nature Geoscience, 6: $701-710$.

Mühlroth, A., Li, K., Røkke, G., Winge, P., Olsen, Y., Hohmann-Marriott, M.F., Vadstein, O. \& Bones, A.M. (2013). Pathways of lipid metabolism in marine algae, coexpression network, bottlenecks and candidate genes for enhanced production of EPA and DHA in species of Chromista. Marine Drugs, 11: 4662-4697.

Mühlroth, A., Winge, P., Assimi, A.E., Jouhet, J., Marechal, E., Hohmann-Marriott, M.F., Vadstein, O. \& Bones, A.M. (2017). Mechanisms of phosphorus acquisition and lipid class remodelling under P limitation in a marine microalga. Plant Physiology, 175: 1543-1559. 
Murphy, J. \& Riley, J.P. (1958). A single-solution method for the determination of soluble phosphate in sea water. Journal of the Marine Biological Association of the United Kingdom, 37: 9-14.

Mus, F., Toussaint, J.-P., Cooksey, K.E., Fields, M.W., Gerlach, R., Peyton, B.M. \& Carlson, R.P. (2013). Physiological and molecular analysis of carbon source supplementation and $\mathrm{pH}$ stress-induced lipid accumulation in the marine diatom Phaeodactylum tricornutum. Applied Microbiology and Biotechnology, 97: 36253642.

Nguyen-Deroche, T.L.N., Caruso, A., Le, T.T., Bui, T.V., Schoefs, B., Tremblin, G. \& Morant-Manceau, A. (2012). Zinc affects differently growth, photosynthesis, antioxidant enzyme activities and phytochelatin synthase expression of four marine diatoms. The Scientific World Journal, 2012: 982957.

Olenina, I., Hajdu, S., Edler, L., Andersson, A., Wasmund, N., Busch, S., Göbel, J., Gromisz, S., Huseby, S., Huttunen, M., Jaanus, A., Kokkonen, P., Jurgensone, I. \& Niemkiewicz, E. (2006). Biovolumes and size-classes of phytoplankton in the Baltic Sea. HELCOM Baltic Sea Environment Proceedings, 106. Helsinki.

Pahlow, M. \& Oschlies, A. (2009). Chain model of phytoplankton P, N and light colimitation. Marine Ecology Progress Series, 376: 69-83.

Pfaffl, M.W., Tichopad, A., Prgomet, C. \& Neuvians, T.P. (2004). Determination of stable housekeeping genes, differentially regulated target genes and sample integrity: BestKeeper - Excel-based tool using pair-wise correlations. Biotechnology Letters, 26: 509-515.

Popko, J., Herrfurth, C., Feussner, K., Ischebeck, T., Iven, T., Haslam, R., Hamilton, M., Sayanova, O., Napier, J., Khozin-Goldberg, I. \& Feussner, I. (2016). Metabolome 
analysis reveals betaine lipids as major source for triglyceride formation, and the accumulation of sedoheptulose during nitrogen-starvation of Phaeodactylum tricornutum. PLoS One, 11: e0164673.

Remmers, I.M., Martens, D.E., Wijffels, R.H. \& Lamers, P.P. (2017). Dynamics of triacylglycerol and EPA production in Phaeodactylum tricornutum under nitrogen starvation at different light intensities. PLoS One, 12: e0175630.

Roháček, K., Bertrand, M., Moreau, B., Jacquette, B., Caplat, C., Morant-Manceau, A. \& Schoefs, B. (2014). Relaxation of the non-photochemical chlorophyll fluorescence quenching in diatoms: kinetics, components and mechanisms. Philosophical Transactions of the Royal Society B, 369: 20130241.

Roháček, K., Soukupová, J. \& Barták, M. (2008). Chlorophyll fluorescence: a wonderful tool to study plant physiology and plant stress. In Plant Cell CompartmentsSelected Topics. (Schoefs, B., editor), 41-104. Research Signpost, Kerala.

Satoh, A., Ichii, K., Matsumoto, M., Kubota, C., Nemoto, M., Tanaka, M., Yoshino, T., Matsunaga, T. \& Tanaka, T. (2013). A process design and productivity evaluation for oil production by indoor mass cultivation of a marine diatom, Fistulifera sp. JPCC DA0580. Bioresource Technology, 137: 132-138.

Scala, S. \& Bowler, C. (2001). Molecular insights into the novel aspects of diatom biology. Cellular and Molecular Life Sciences, 58: 1666-1673.

Shemi, A., Schatz, D., Fredricks, H.F., Van Mooy, B.A.S., Porat, Z. \& Vardi, A. (2016). Phosphorus starvation induces membrane remodeling and recycling in Emiliania huxleyi. New Phytologist, 211: 886-898.

Simionato, D., Block, M.A., La Rocca, N., Jouhet, J., Maréchal, E., Finazzi, G. \& Morosinotto, T. (2013). The response of Nannochloropsis gaditana to nitrogen 
starvation includes de novo biosynthesis of triacylglycerols, a decrease of chloroplast galactolipids, and reorganization of the photosynthetic apparatus. Eukaryotic Cell, 12: 665-676.

Slover, H.T. \& Lanza, E. (1979). Quantitative analysis of food fatty acids by capillary gas chromatography. Journal of the American Oil Chemists' Society, 56: 933.

Terry, K.L., Hirata, J. \& Laws, E.A. (1985). Light-, nitrogen-, and phosphorus-limited growth of Phaeodactylum tricornutum Bohlin strain TFX-1: Chemical composition, carbon partitioning, and the diel periodicity of physiological processes. Journal of Experimental Marine Biology and Ecology, 86: 85-100.

Theodorou, M. E., Elrifi, I. R., Turpin, D. H. \& Plaxton, W. C. (1991). Effects of phosphorus limitation on respiratory metabolism in the green alga Selenastrum minutum. Plant Physiology, 95: 1089-1095.

Valenzuela, J., Mazurie, A., Carlson, R.P., Gerlach, R., Cooksey, K.E., Peyton, B.M. \& Fields, M.W. (2012). Potential role of multiple carbon fixation pathways during lipid accumulation in Phaeodactylum tricornutum. Biotechnology for Biofuels, 5: 40.

Van Mooy, B.A.S., Fredricks, H.F., Pedler, B.E., Dyhrman, S.T., Karl, D.M., Koblížek, M., Lomas, M.W., Mincer, T.J., Moore, L.R., Moutin, T., Rappé, M.S. \& Webb, E.A. (2009). Phytoplankton in the ocean use non-phosphorus lipids in response to phosphorus scarcity. Nature, 458: 69-72.

Walne, P.R. (1966). Experiments in the large-scale culture of the larvae of Ostrea edulis L. Fishery investigations, ser. 2, 25. London.

White, T., Bursten, S., Federighi, D., Lewis, R.A. \& Nudelman, E. (1998). Highresolution separation and quantification of neutral lipid and phospholipid species 
in mammalian cells and sera by multi-one-dimensional thin-layer chromatography. Analytical Biochemistry, 258: 109-117.

Wilhelm, C., Büchel, C., Fisahn, J., Goss, R., Jakob, T., LaRoche, J., Lavaud, J., Lohr, M., Riebesell, U., Stehfest, K., Valentin, K. \& Kroth, P.G. (2006). The regulation of carbon and nutrient assimilation in diatoms is significantly different from green algae. Protist, 157: 91-124.

Wykoff, D.D., Davies, J.P., Melis, A. \& Grossman, A.R. (1998). The regulation of photosynthetic electron transport during nutrient deprivation in Chlamydomonas reinhardtii. Plant Physiology, 117: 129-139.

Yang, Z.-K., Niu, Y.-F., Ma, Y.-H., Xue, J., Zhang, M.-H., Yang, W.-D., Liu, J.-S., Lu, S.-H., Guan, Y.\& Li, H.-Y. (2013). Molecular and cellular mechanisms of neutral lipid accumulation in diatom following nitrogen deprivation. Biotechnology for Biofuels, 6: 67.

Yang, Z.-K., Zheng, J.-W., Niu, Y.-F., Yang, W.-D., Liu, J.-S. \& Li, H.-Y. (2014). Systems-level analysis of the metabolic responses of the diatom Phaeodactylum tricornutum to phosphorus stress. Environmental Microbiology, 16: 1793-1807.

Yoon, K., Han, D., Li, Y., Sommerfeld, M. \& Hu, Q. (2012). Phospholipid:diacylglycerol acyltransferase is a multifunctional enzyme involved in membrane lipid turnover and degradation while synthesizing triacylglycerol in the unicellular green microalga Chlamydomonas reinhardtii. The Plant Cell, 24: 3708-3724.

Zhao, S. \& Fernald, R.D. (2005). Comprehensive algorithm for quantitative real-time polymerase chain reaction. Journal of Computational Biology, 12: 1047-1064.

Zienkiewicz, K., Du, Z.-Y., Ma, W., Vollheyde, K. \& Benning, C. (2016). Stress-induced neutral lipid biosynthesis in microalgae - Molecular, cellular and physiological 
insights. Biochimica et Biophysica Acta - Molecular and Cell Biology of Lipids, 1861: 1269-1281. 
A

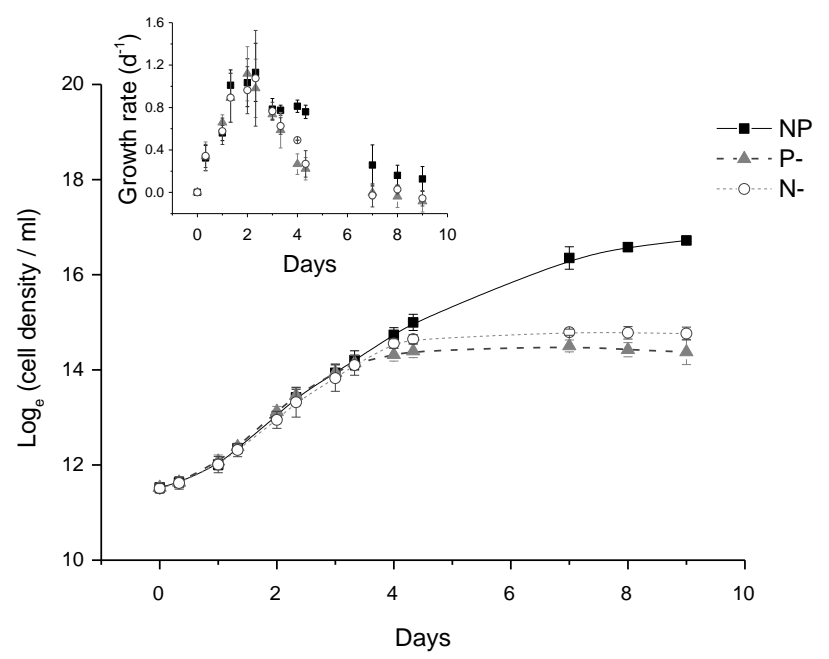

C

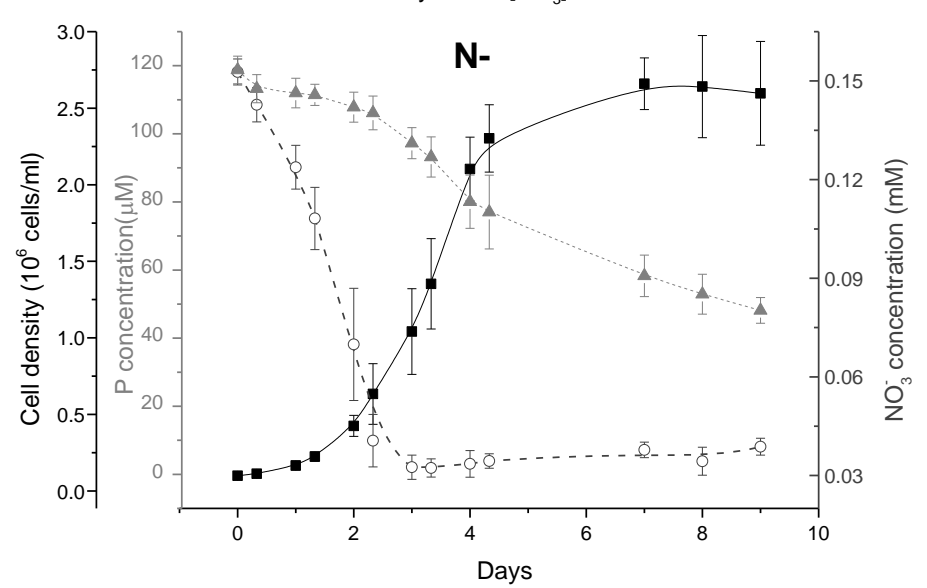

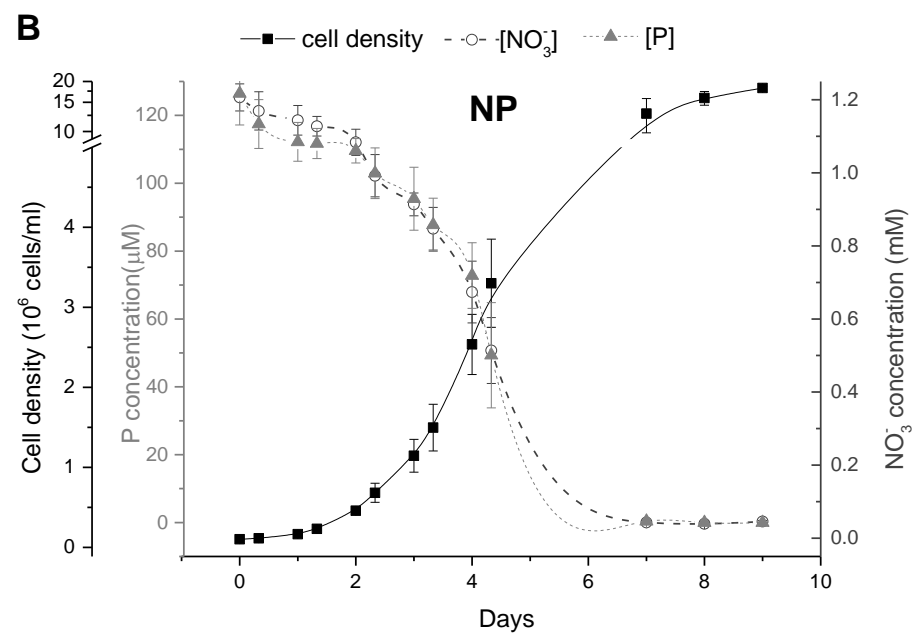

D

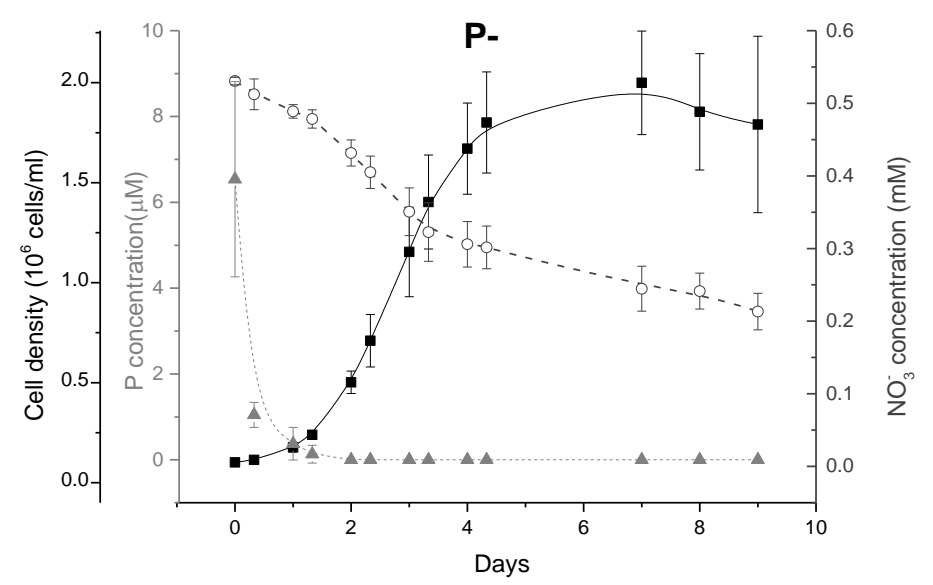

Fig. 1. Growth of P. tricornutum under control (NP), N-limited (N-) or P-limited (P-) conditions over 9 days in batch cultures (Means \pm S.D., $\mathrm{n}=5$ ). (A) Semi-log plot of growth curves (cell density $\mathrm{ml}^{-1}$ ) and specific growth rate $\left(\mathrm{d}^{-1}\right)$ in the insert, $(\mathrm{B})$ Dissolved $\mathrm{NO}_{3}{ }^{-}$concentration $(\mathrm{mM})$ and $\mathrm{P}$ concentration $(\mu \mathrm{M})$ in NP cultures, (C) Dissolved $\mathrm{NO}_{3}{ }^{-}$concentration $(\mathrm{mM})$ and $\mathrm{P}$ concentration $(\mu \mathrm{M})$ in $\mathrm{N}$-limited cultures, (D) Dissolved $\mathrm{NO}_{3}{ }^{-}$ concentration $(\mathrm{mM})$ and $\mathrm{P}$ concentration $(\mu \mathrm{M})$ in P-limited cultures. 
A

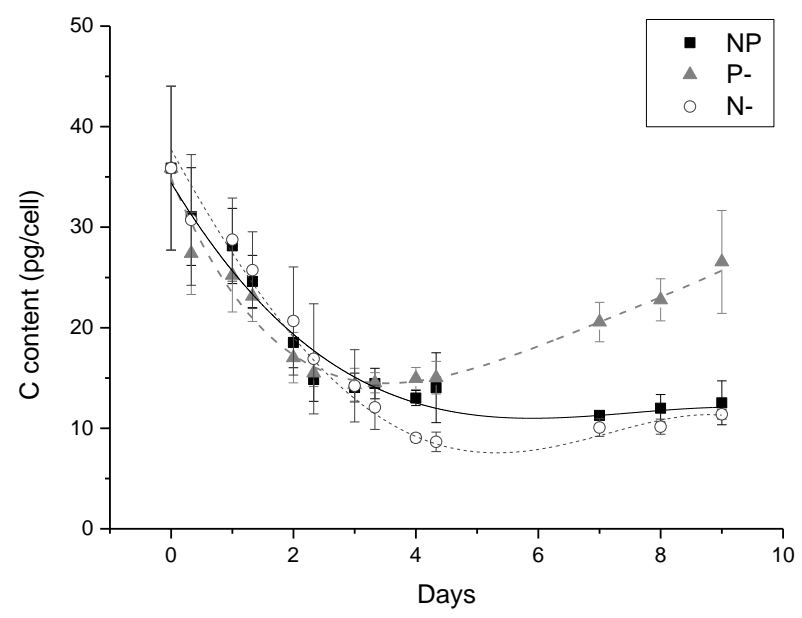

B

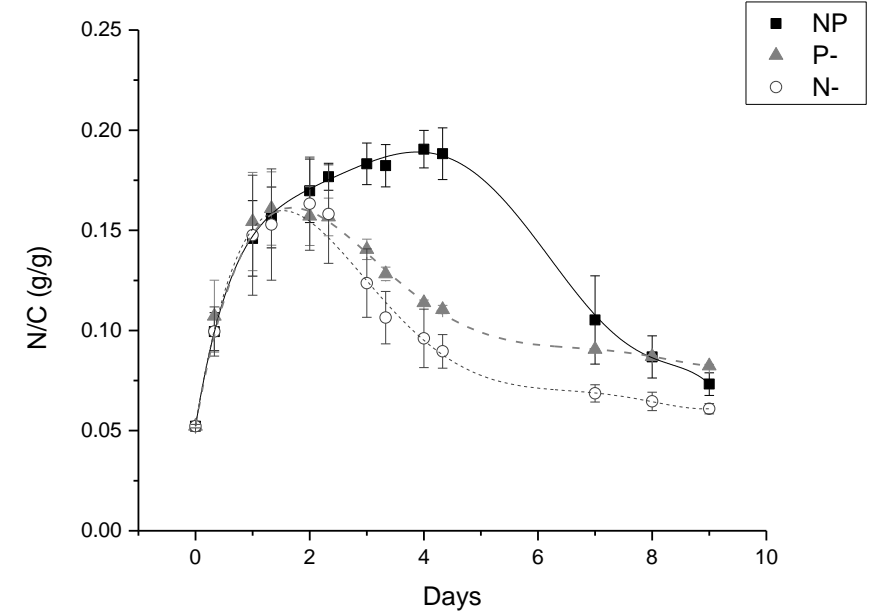

Fig. 2. Particulate carbon and nitrogen in P. tricornutum grown under control (NP), N-limited (N-) or P-limited (P-) conditions over 9 days in batch cultures. (Mean \pm S.D., $\mathrm{n}=3$ ). (A) Carbon content per cell (pg cell-1 ${ }^{-1}$, (B) Nitrogen content per unit cell carbon $(\mathrm{g} / \mathrm{g})$. 
A

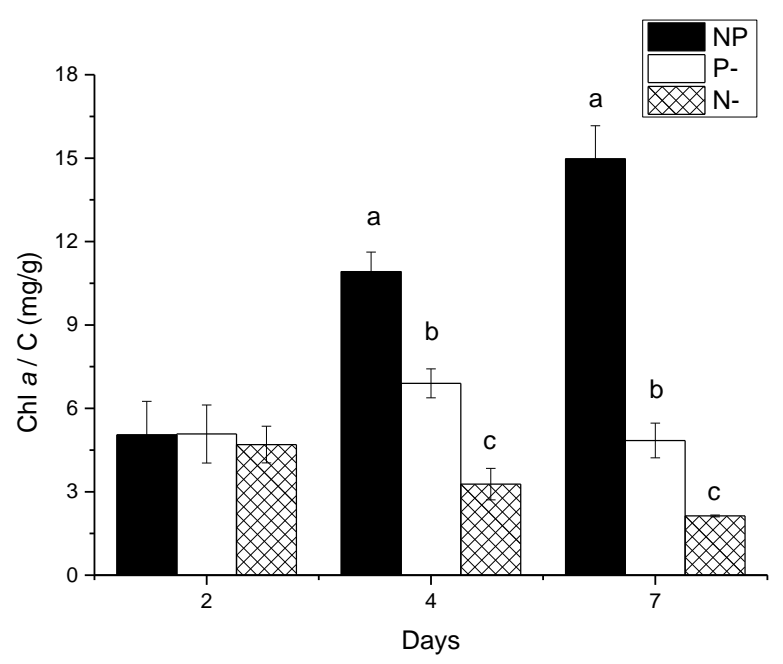

C

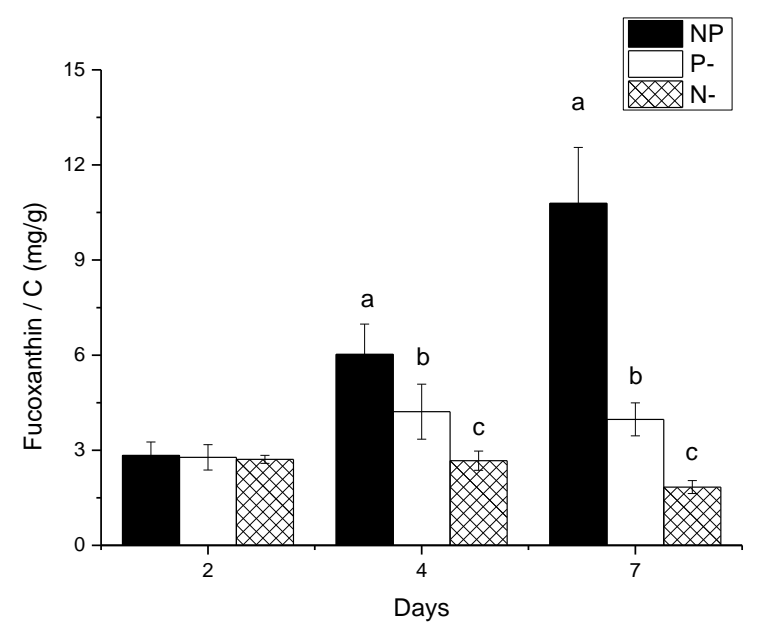

B

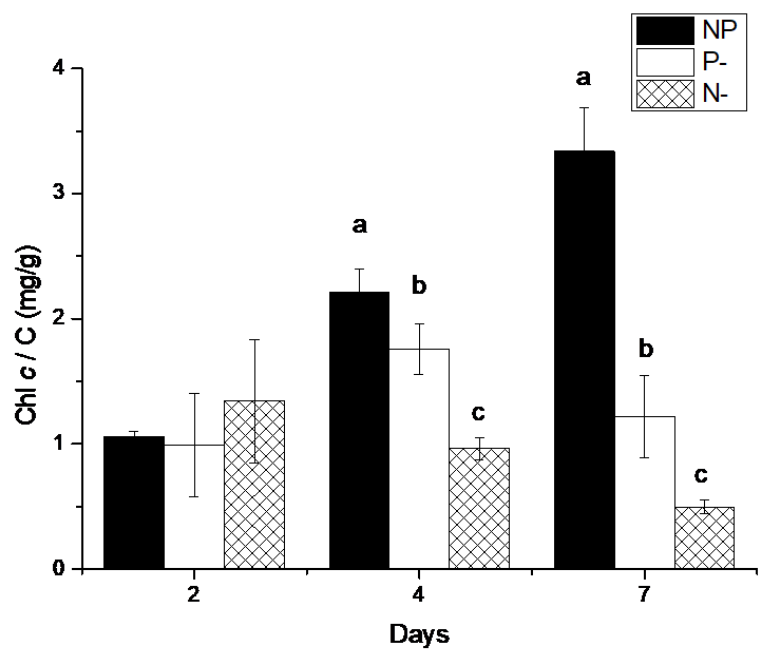

Fig. 3. Pigment contents of $P$. tricornutum grown under control (NP), N-limited (N-) or P-limited (P-) conditions (Mean \pm S.D., $\mathrm{n}=3$, different letters indicate significant $(\mathrm{p}<0.05)$ differences at each culture day). (A) Chl $a$ content per unit cell carbon (mg/g), (B) Chl c content per unit cell carbon (mg/g), (C) Fucoxanthin content per unit cell carbon $(\mathrm{mg} / \mathrm{g})$. 
A

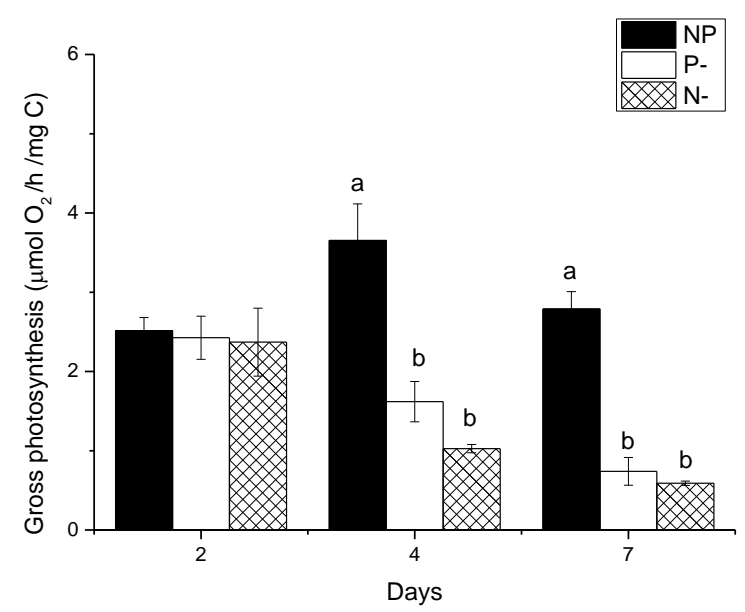

C

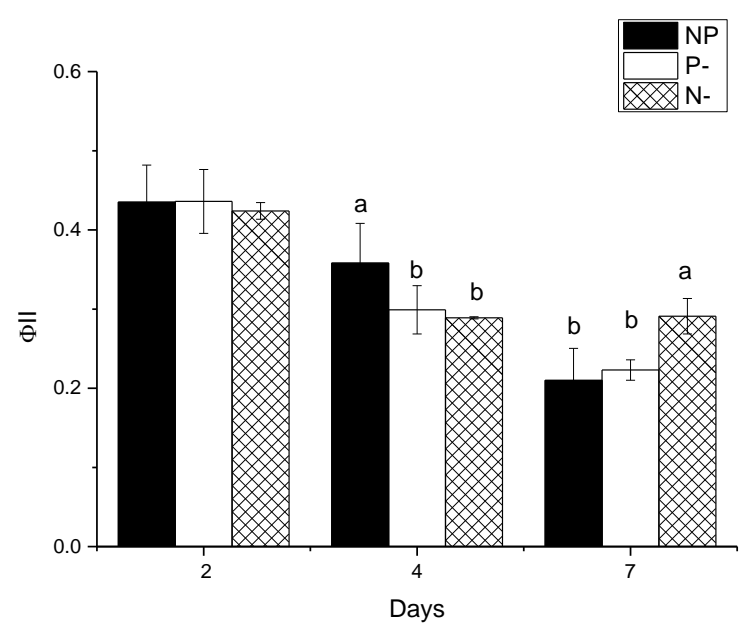

E

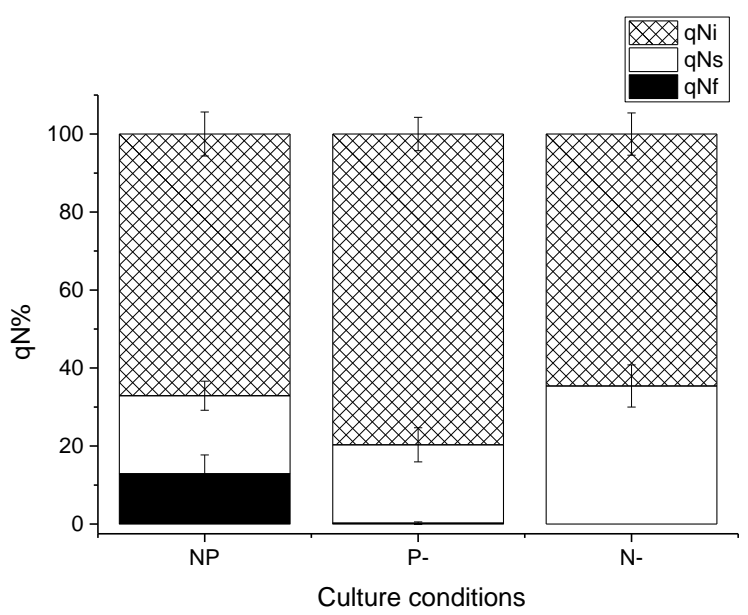

B

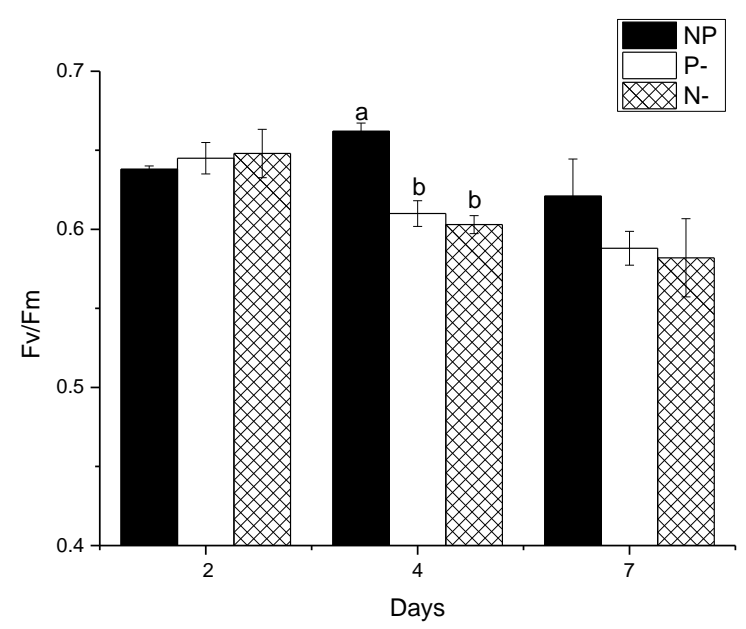

D

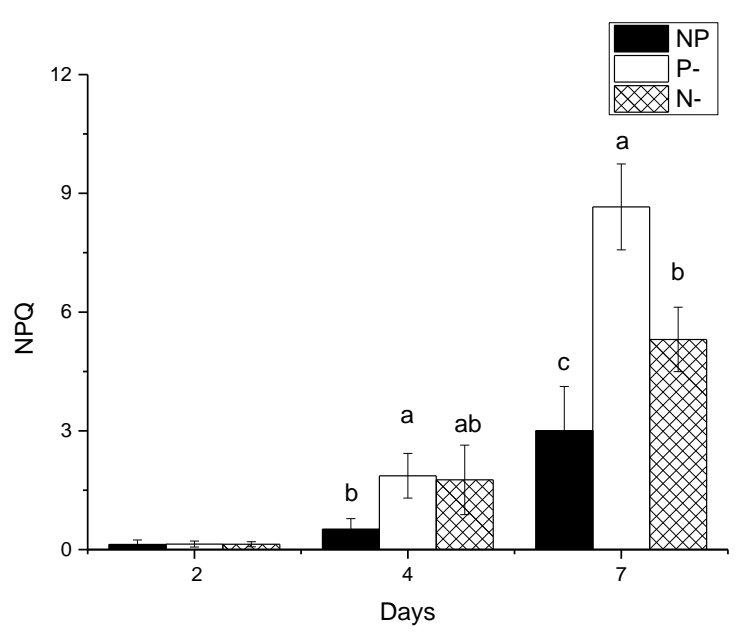


Fig. 4. Physiological parameters of P. tricornutum grown under control (NP), N-limited (N-) or P-limited (P-) conditions. Different letters indicate significant $(\mathrm{p}<0.05)$ differences at each culture day $($ Mean \pm S.D., $n=3)$. (A) Gross photosynthesis per unit cell carbon ( $\left.\mu \mathrm{mol} \mathrm{O}_{2} / \mathrm{h} / \mathrm{mg} \mathrm{C}\right)$, (B) Maximum photochemical efficiency of PSII $\left(\mathrm{F}_{\mathrm{v}} / \mathrm{F}_{\mathrm{m}}\right),(\mathrm{C})$ Effective photochemical efficiency of PSII $\left(\Phi_{\mathrm{II}}\right)$ under $300 \mu \mathrm{mol}$ photons $\mathrm{m}^{-2} \mathrm{~s}^{-1}$, (D) Nonphotochemical quenching (NPQ) under $300 \mu$ mol photons $\mathrm{m}^{-2} \mathrm{~s}^{-1}$, (E) Proportions of $\mathrm{qN}_{\mathrm{f}}, \mathrm{qN}_{\mathrm{i}}$ and $\mathrm{qN}_{\mathrm{s}}$ in $\mathrm{qN}$ after a high irradiance $\left(1000 \mu \mathrm{mol}\right.$ photons $\left.\mathrm{m}^{-2} \mathrm{~s}^{-1}\right)$ on day 4 . 
A

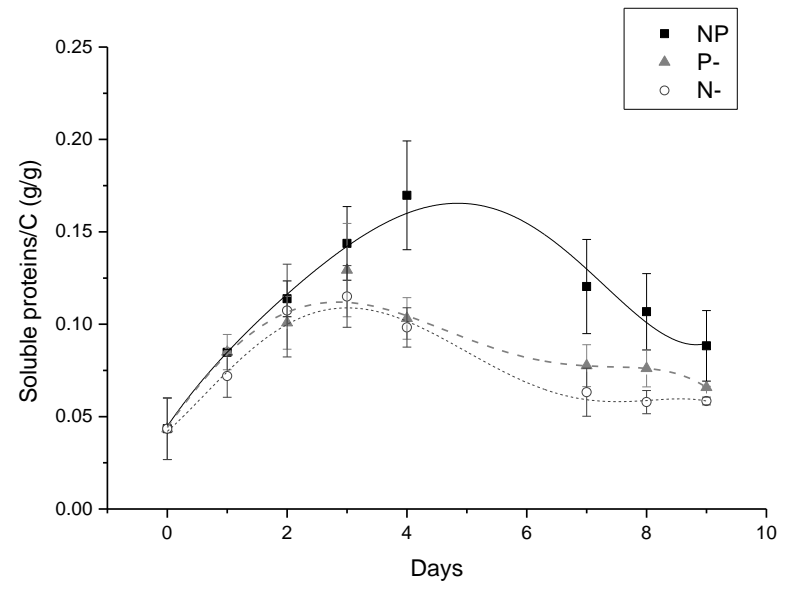

C

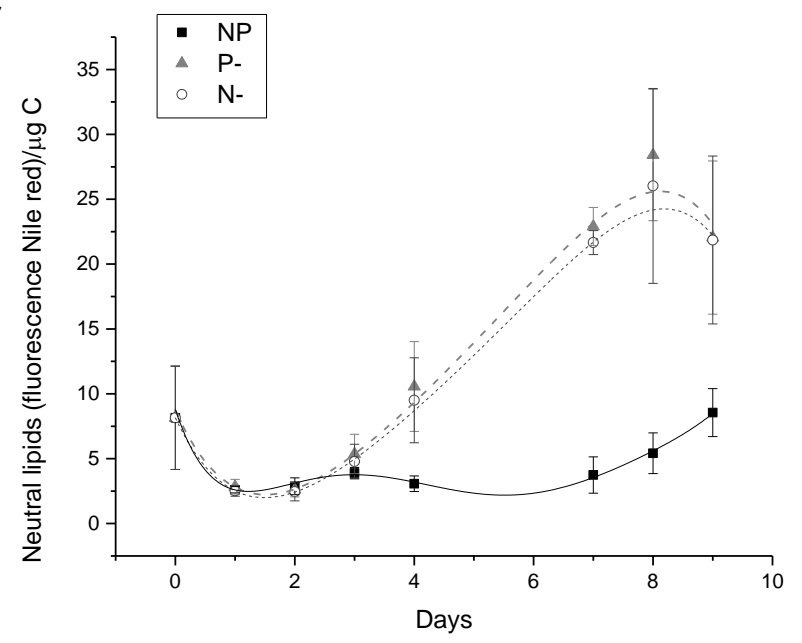

B

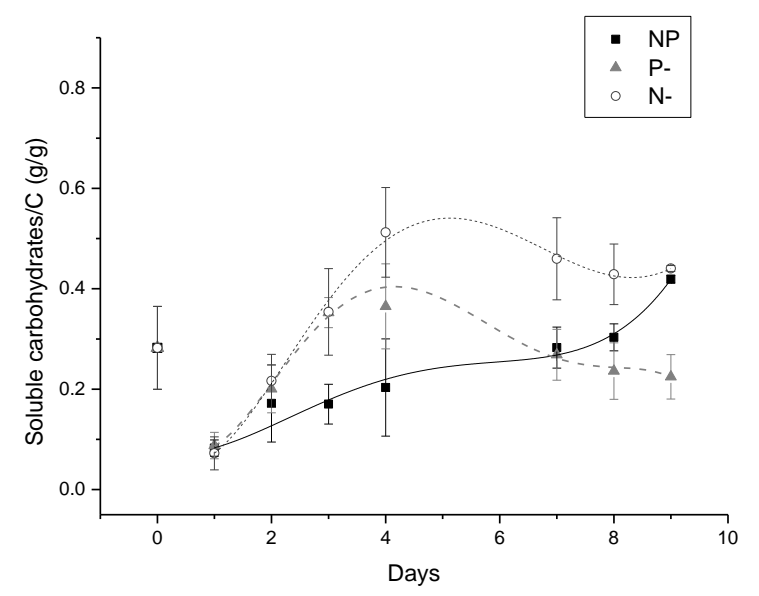

D

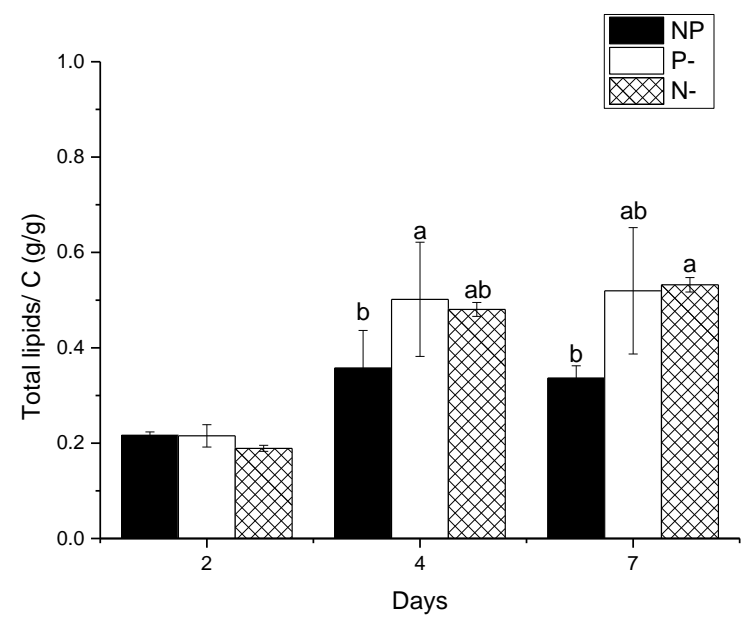

Fig. 5. Proximate biochemical composition of P. tricornutum grown under control (NP), N-limited (N-) or Plimited (P-) conditions over 9 days in batch cultures. (Mean \pm S.D., $n=3$ ). (A) Soluble protein content per unit cell carbon $(\mathrm{g} / \mathrm{g})$, (B) Soluble carbohydrate content per unit cell carbon $(\mathrm{g} / \mathrm{g}),(\mathrm{C})$ Fluorescence of microalgae cells stained with Nile red per unit cell carbon $\left(\mu \mathrm{g} \mathrm{C}^{-1}\right)$ as measurements of neutral lipid content, (D) Total lipid content per unit cell carbon $(\mathrm{g} / \mathrm{g})$. 
A

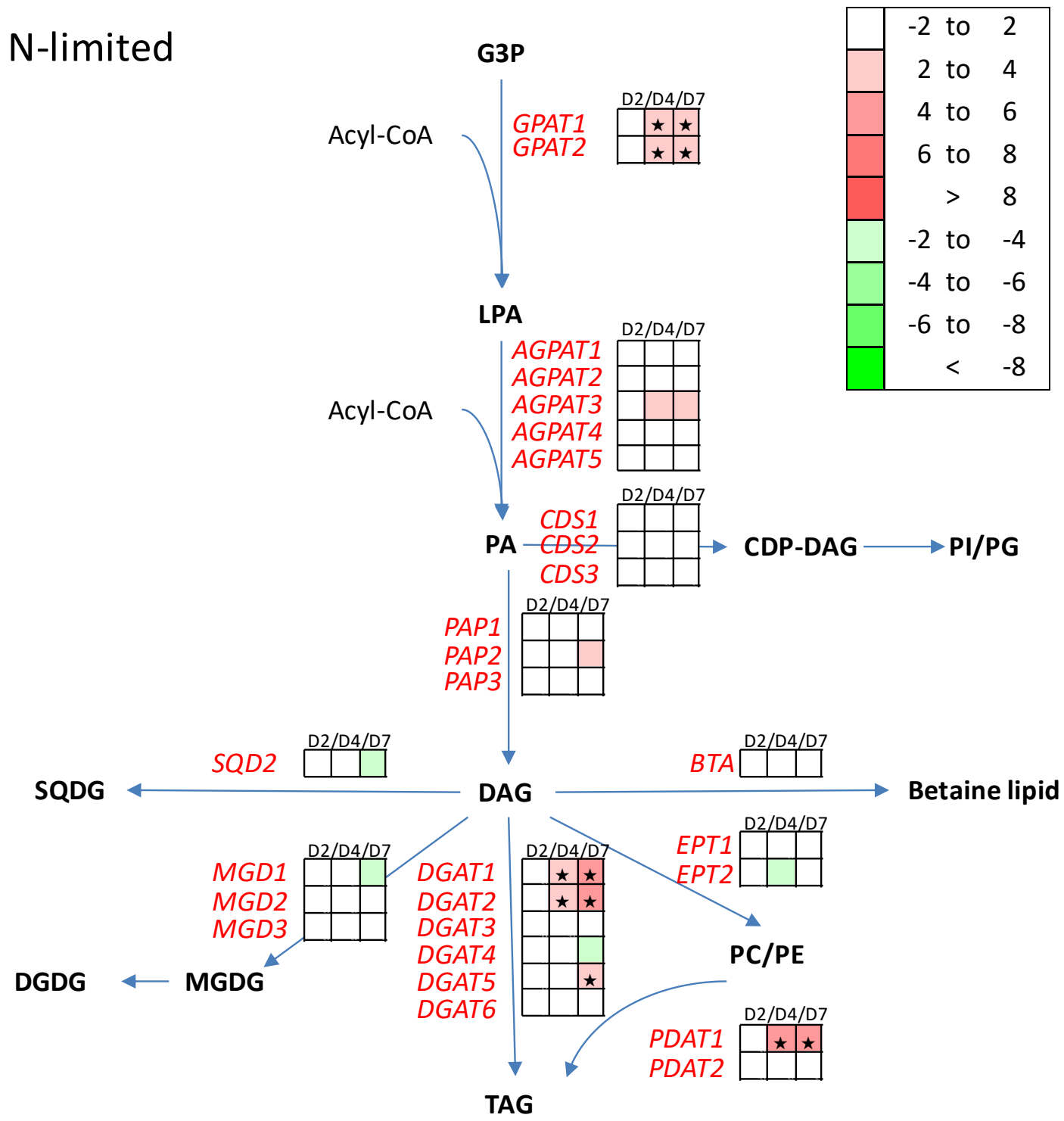


B

\section{P-limited}

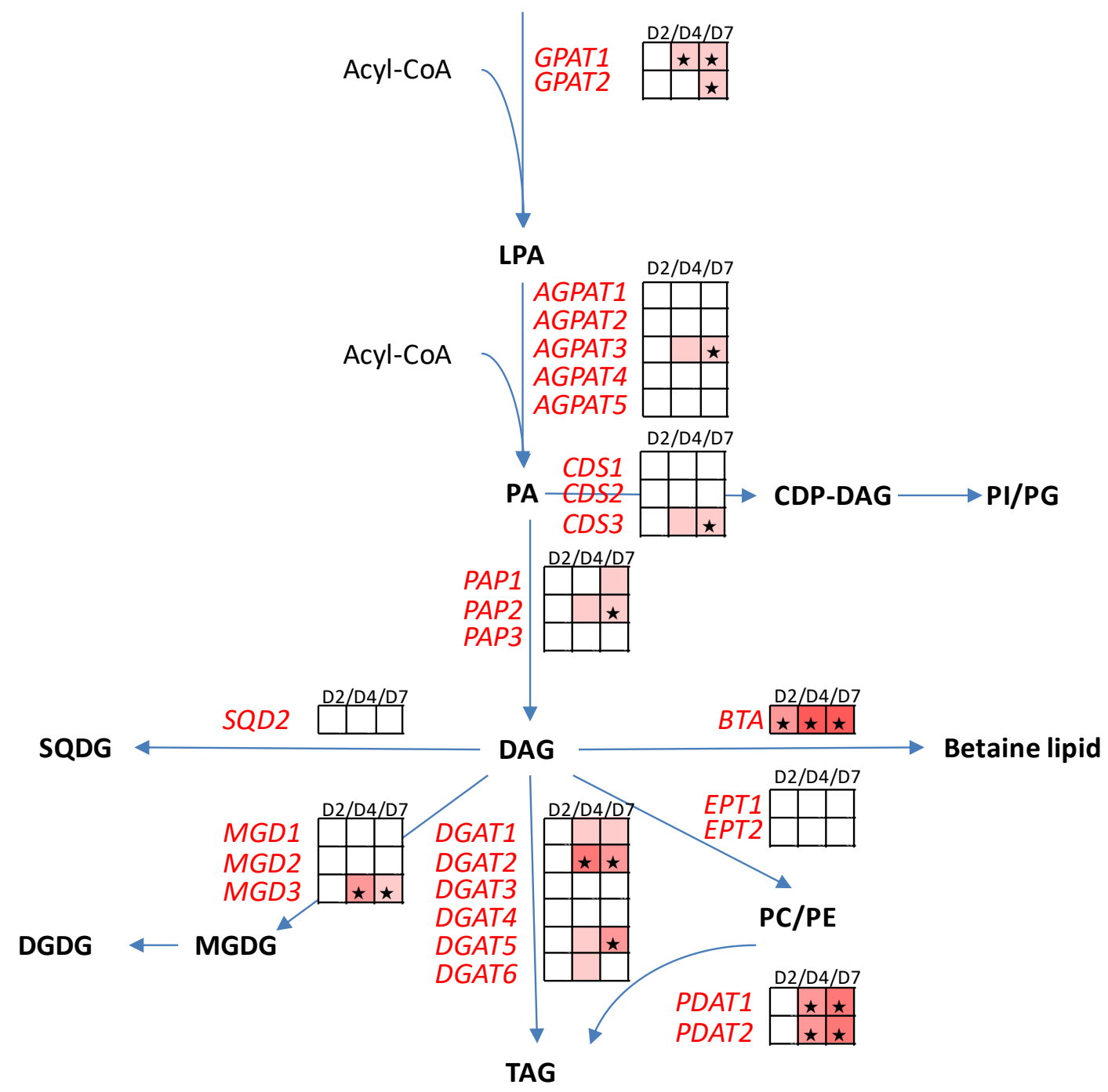

Fig. 6. Transcriptional fold changes, from triplicate cultures, under (A) N-limited (N-) or (B) P-limited (P-) conditions of 28 genes/isogenes coding for 10 enzymes involved in TAG and membrane lipid biosynthetic pathways in P.tricornutum. Colored squares indicate the regulation pattern on days 2, 4 and 7 (red, upregulated; green, downregulated). For both N- and P-limited conditions, day-2 control cultures were used as calibrator. Asterisks indicate significant regulation compared with day- 2 control cultures $\left(p<0.01\right.$ and $\left[\log _{2}\right.$ fold $>1$ or $\log _{2}$ fold $\left.<-1\right]$ or $p<0.05$ and $\left[\log _{2}\right.$ fold $>2$ or $\log _{2}$ fold $\left.<-2\right]$ ). See Supplementary Table S1 for correspondence between gene abbreviations and protein ID. CDP-DAG, cytidine diphosphate diacylglycerol; DAG, 
diacylglycerol; DGDG, digalactosyldiacylglycerol; G3P, glycerol-3-phosphate; LPA, lysophosphatidic acid; MGDG, monogalactosyldiacylglycerol; PA, phosphatidic acid; PC, phosphatidylcholine; PE, phosphatidylethanolamine; PG, phosphatidylglycerol; PI, phosphatidylinositol; SQDG, sulfoquinovosyldiacylglycerol; TAG, triacylglycerol. 
A

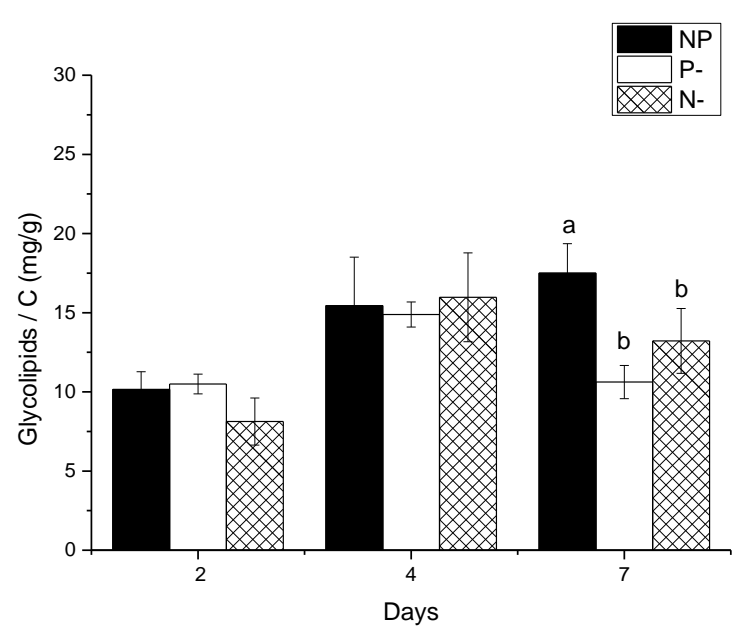

A-2

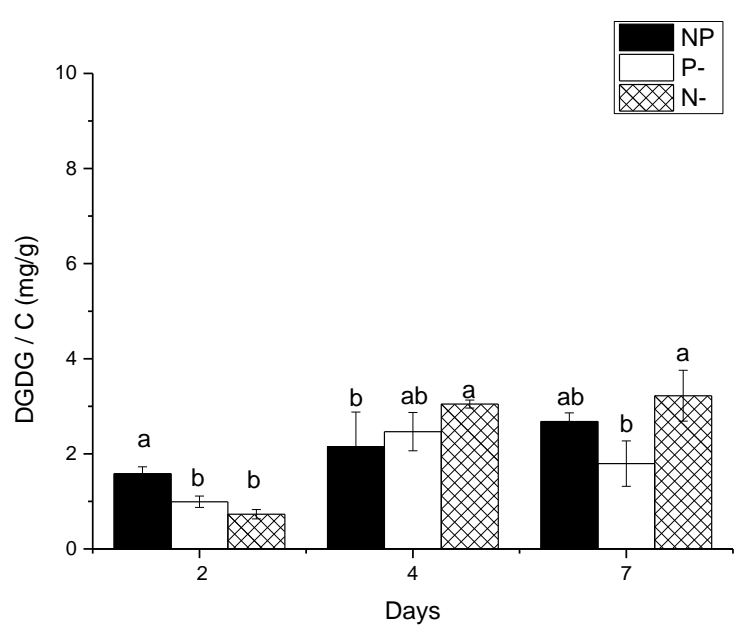

B

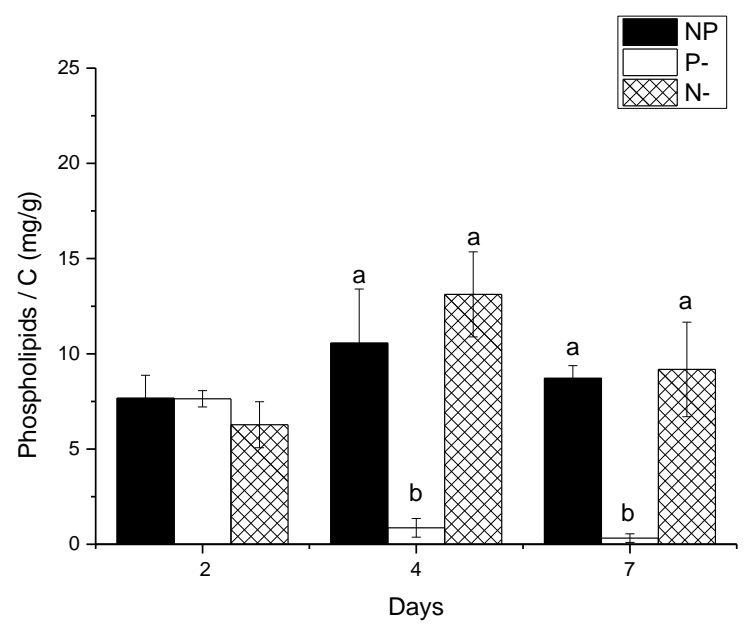

A-1

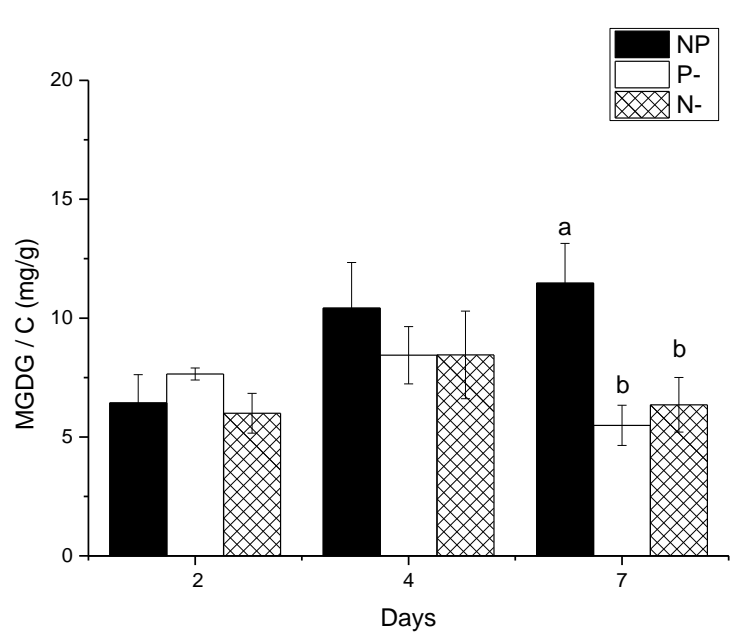

A-3

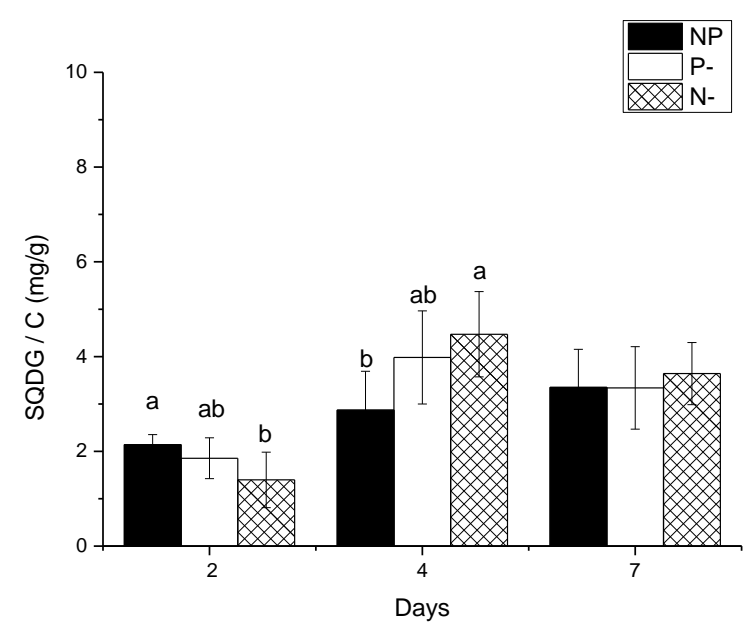

B-1

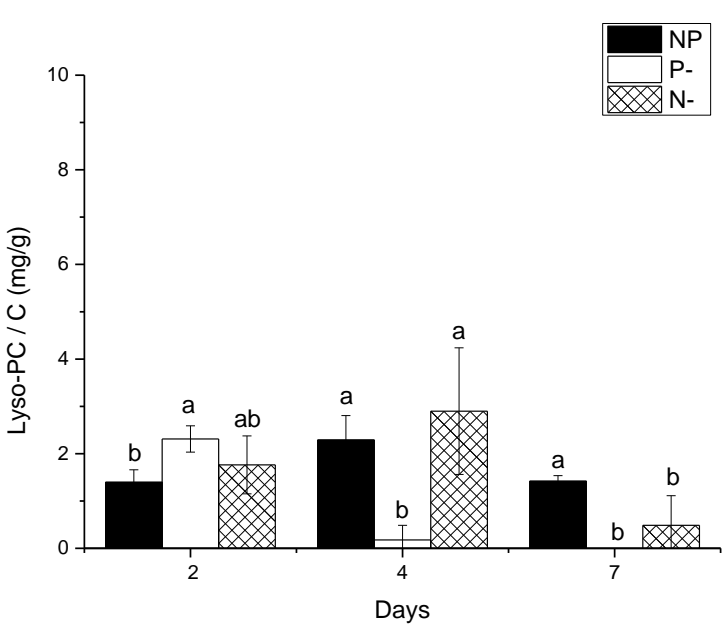


B-2

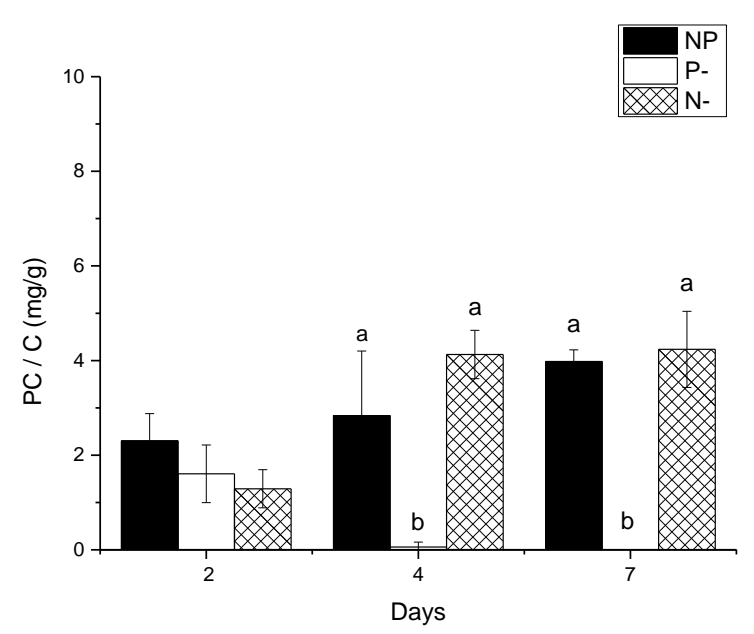

\section{B-4}

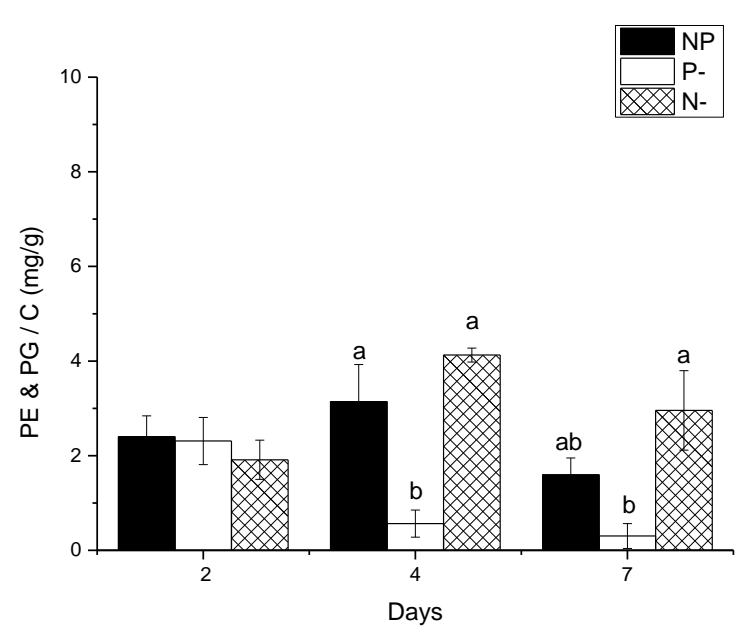

C

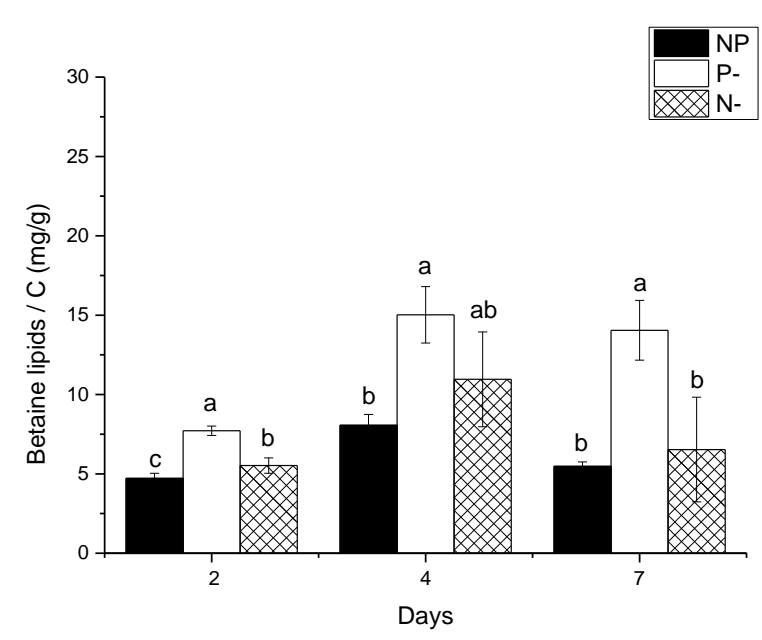

B-3

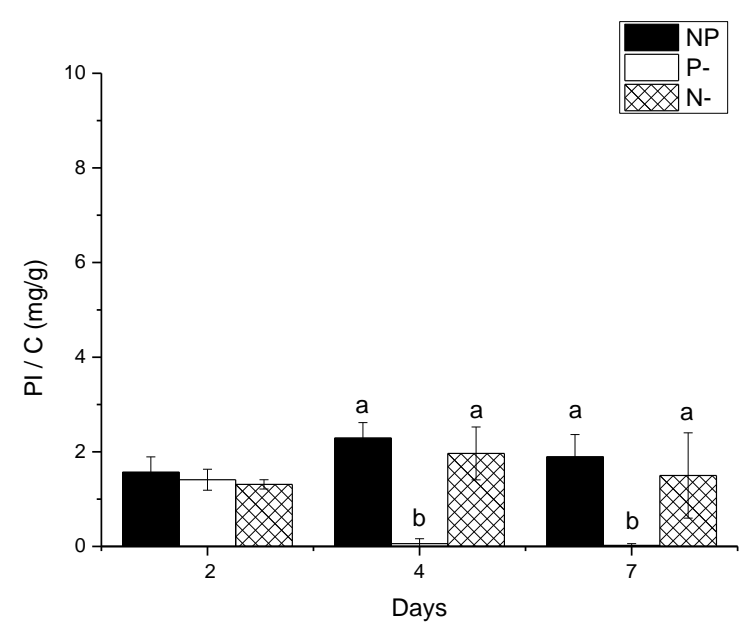

C-1

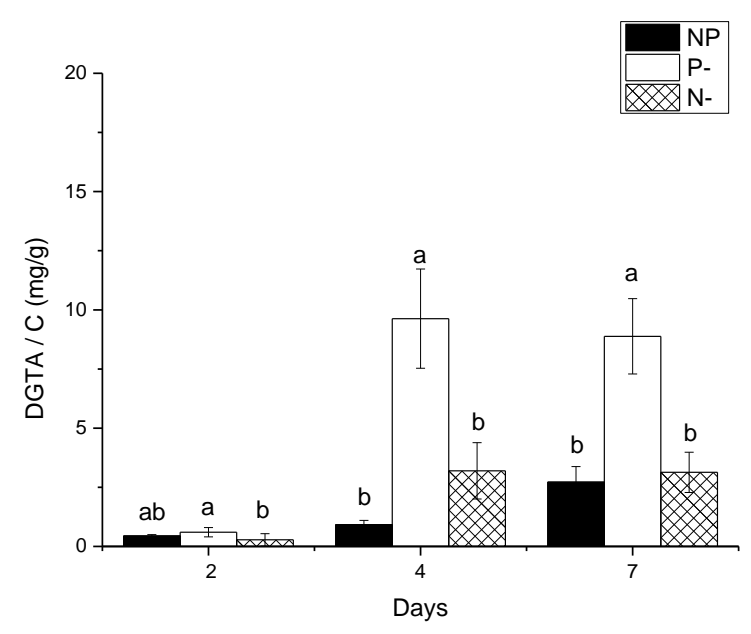




\section{C-2}

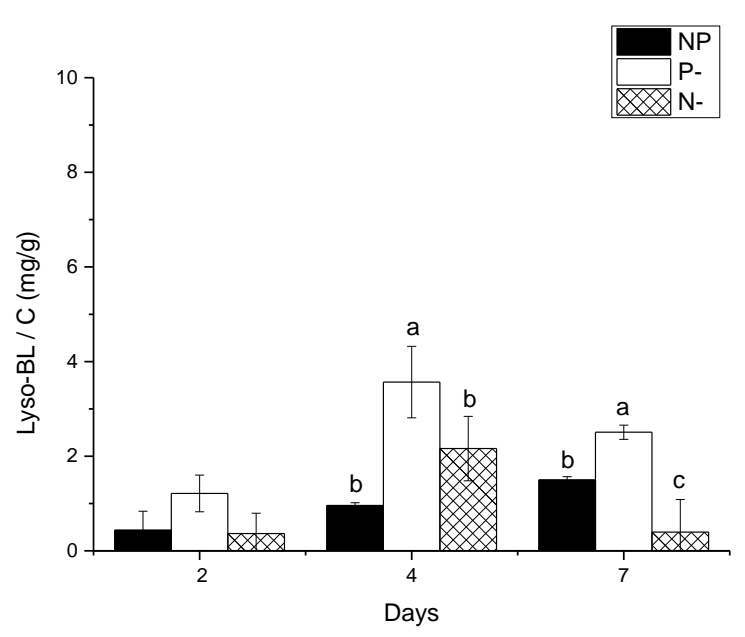

C-3

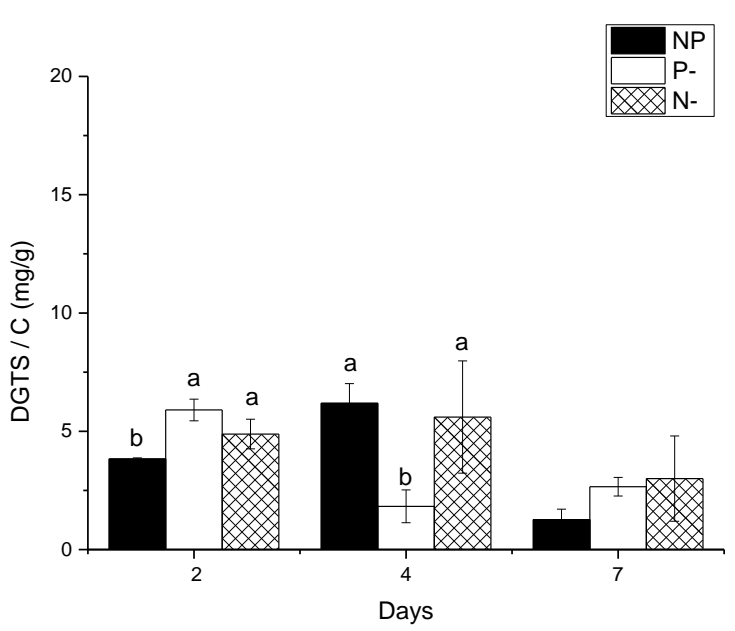

Fig. 7. Quantitative analysis of lipid classes extracted from P. tricornutum grown under control (NP), N-limited $(\mathrm{N}-)$ or P-limited $(\mathrm{P}-)$ conditions. Different letters indicate significant $(\mathrm{p}<0.05)$ differences at each culture day (Mean \pm S.D., $n=3$ ). (A) Glycolipids (GL): A-1. MGDG, monogalactosyldiacylglycerol, A-2. DGDG, digalactosyldiacylglycerol, A-3. SQDG, sulfoquinovosyldiacylglycerol; (B) Phospholipids (PL): B-1. Lyso-PC, B-2. PC, phosphatidylcholine, B-3. PI, phosphatidylinositol, B-4. PE, phosphatidylethanolamine and PG, phosphatidylglycerol; (C) Betaine lipids (BL): C-1. DGTA, diacylglyceryl-hydroxymethyl-trimethyl- $\beta$-alanine, C-2. lyso-BL, C-3. DGTS, diacylglycerol-trimethylhomoserine. 
A

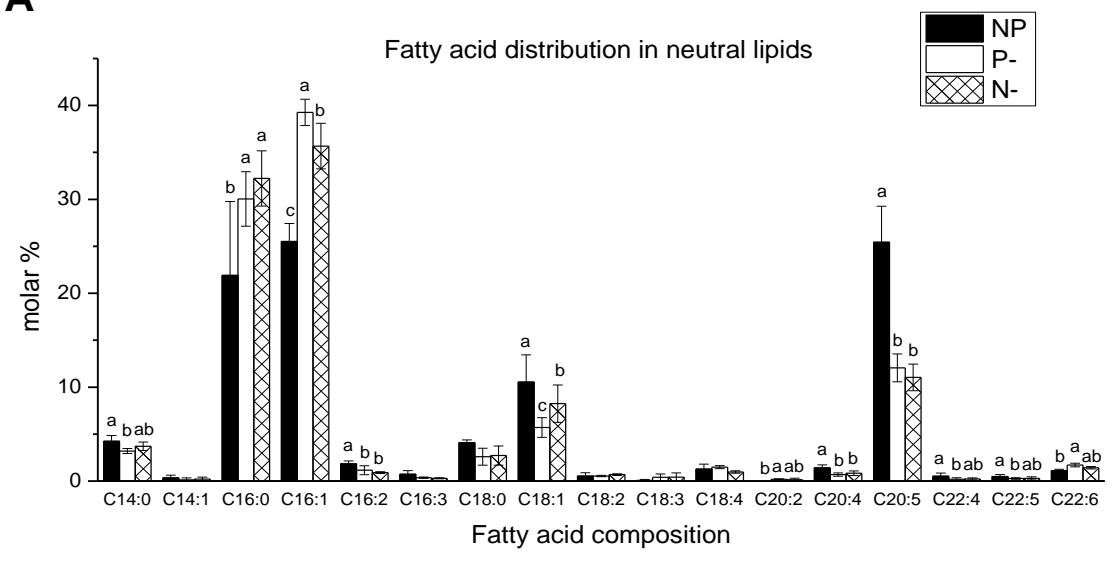

B

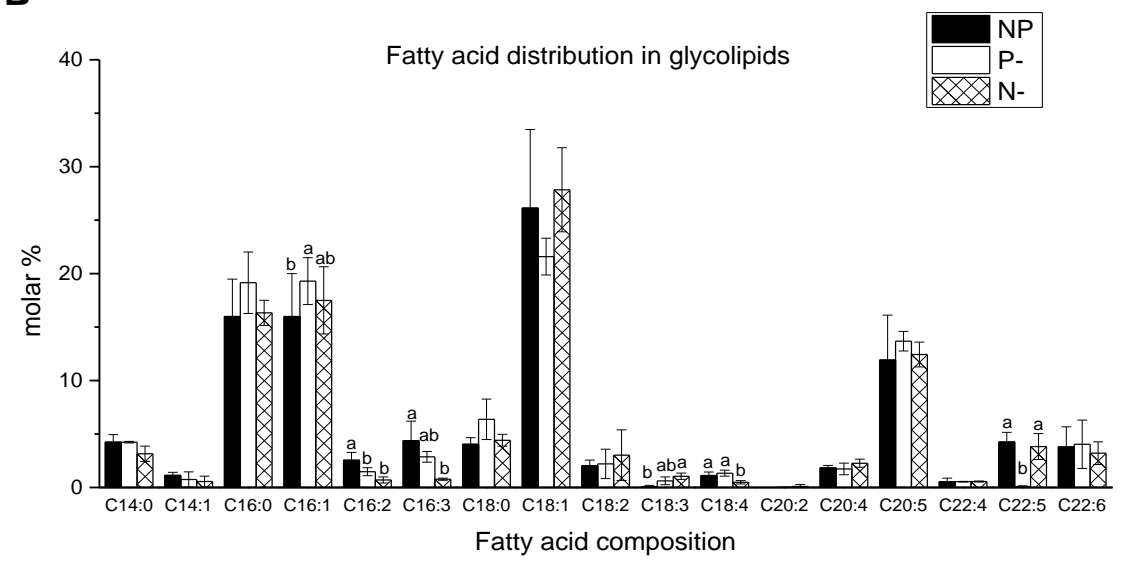

C

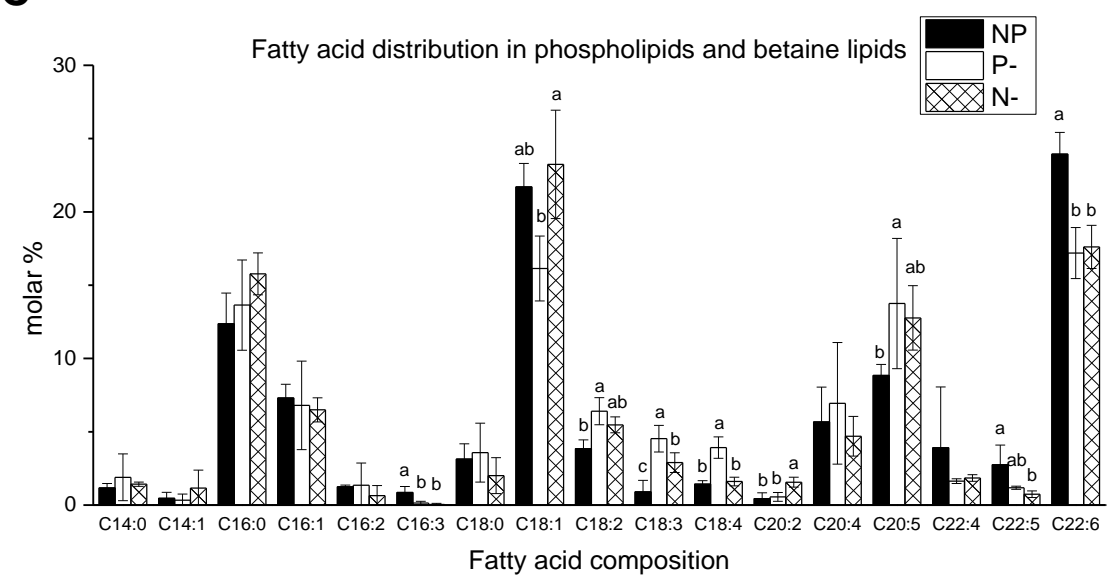


Fig. 8. Fatty acid distribution in three main fractions of lipids extracted from P. tricornutum grown under control (NP), N-limited (N-) or P-limited (P-) conditions on day 4. Different letters indicate significant $(\mathrm{p}<0.05)$ differences (Mean \pm S.D., $n=3$ ). (A) Fatty acid distribution in neutral lipids, (B) Fatty acid distribution in glycolipids, (C) Fatty acid distribution in phospholipids and betaine lipids. Fatty acids: C14:0, myristic acid; C14:1n-5, myristoleic acid; C16:0, palmitic acid; C16:1n-7, palmitoleic acid; C16:2n-6, hexadecadienoic acid; C16:3n-4, hexadecatrienoic acid, C18:0, stearic acid; C18:1n-9, oleic acid; C18:2n-6, linoleic acid; C18:3n-3, $\alpha-$ linolenic acid; C18:4n-3, stearidonic acid; C20:2n-6, eicosadienoic acid; C20:4n-6, arachidonic acid; C20:5n-3, eicosapentaenoic acid; C22:4n-6, docosatetraenoic acid; C22:5n-3, docosapentaenoic acid; C22:6n-3, docosahexaenoic acid. 